زيستفراهمى برخى عناصر ريزمغذى تحت تأثير بيوجار و كميوست بقاياى هرس درختان در

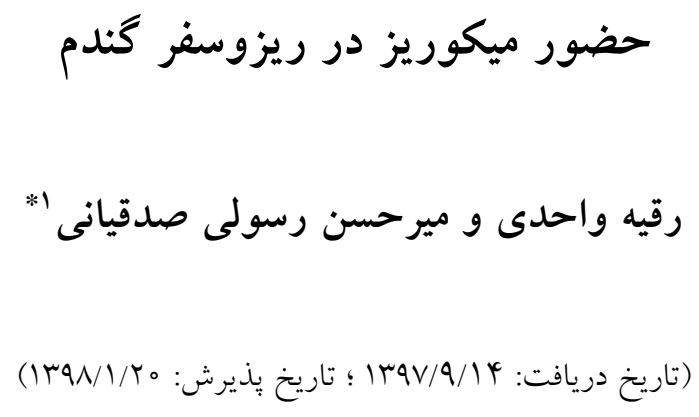

جكيده

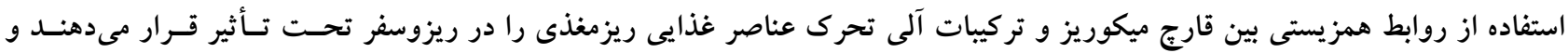

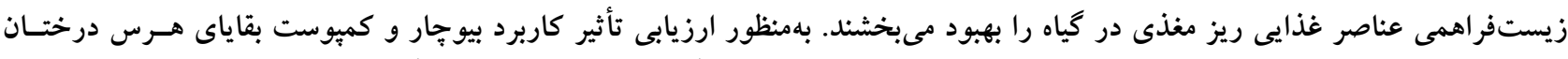

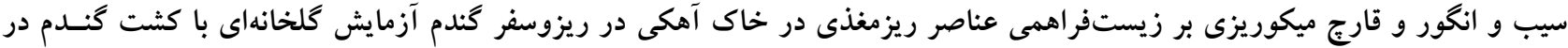

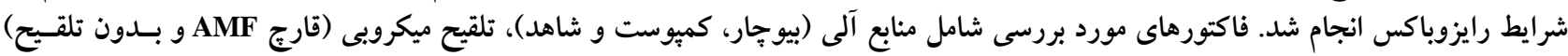

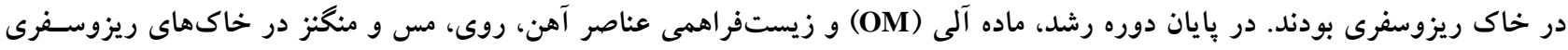

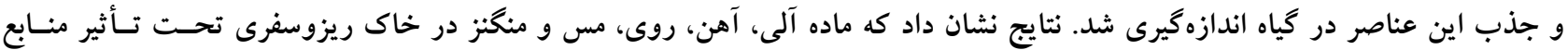

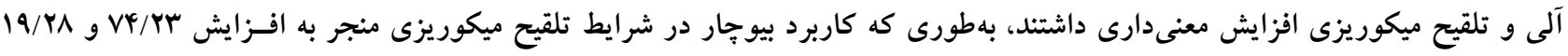

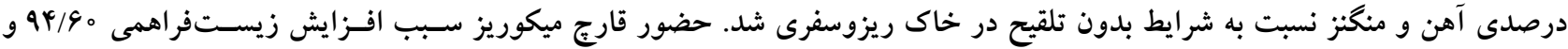

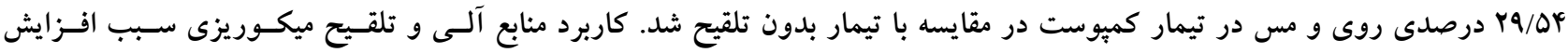

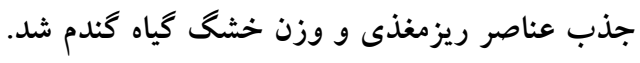

وازههاى كليدى: مواد آلى، عناصر ريزمغذى، ريزوسفر، گندم 
كشتشده در تيمارهاى شاهد و كميوست در مقايسه با لجن

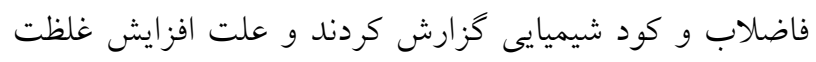

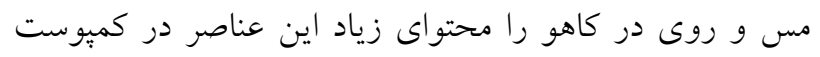

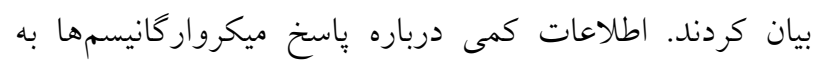

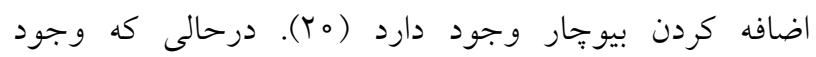

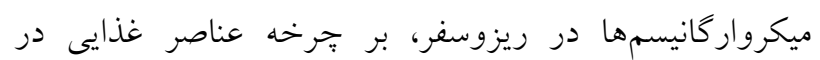

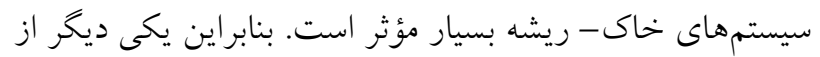
راهكارهاى افزايش زيستفراهمى عناصر ريزمغذى استفاده از

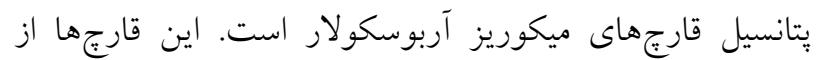
طريق مكانيسمهاى مختلفى حلاليت عناصر موجود در خاك را

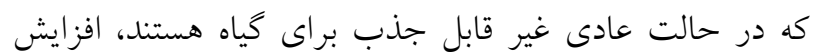
مىدهند و با كسترده كردن شبكه هيفهاى خود در خاك، افزايش سطح و سرعت جذب ريشه كياه را نيز افزايش مىدهند (YY) (Y). نتايج نشان داده است كه اثر همزيستى قارجهاى

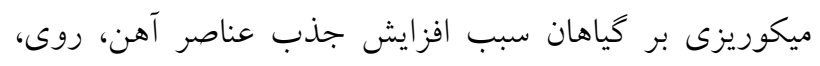

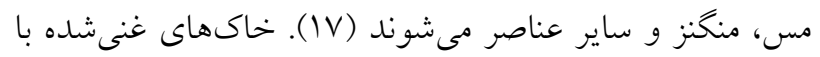

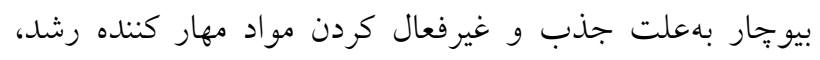

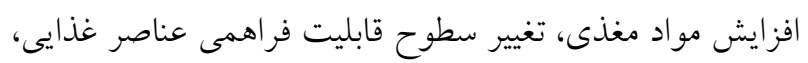
حفاظت فيزيكى مستقيم قارجهاى ميكوريزى از تغذئيه

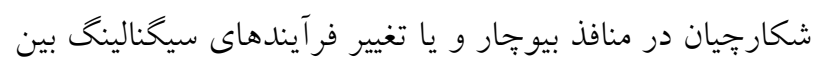
كياه و قارجهاى ميكوريزى با تغيير ديناميك اين قارجها همر همراه

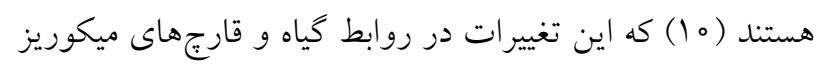

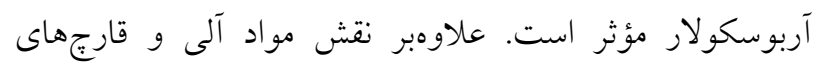

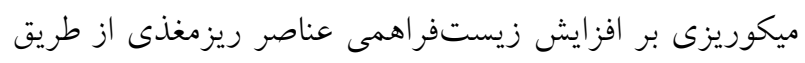

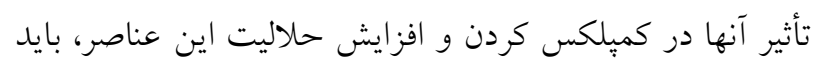
به تأثير ريزوسفر نيز توجه كرد. جريانات كربن در ايفاى نقش منطقه ريزوسفر بسيار اهميت دارد (YY). ريزوسفر محيطى

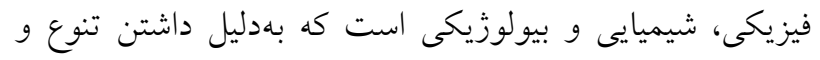
فعاليت ميكروبى از خاك غيرريزوسفرى متمايز مى شود. عرضه

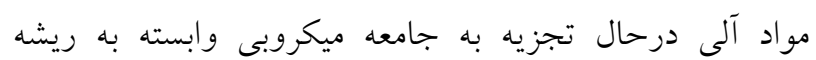
همراه با تغييرات ميكروبى ايجاد شده در الكوهاى ريشهبندى و عرضه عناصر غذايى فراهم براى كياه كه از فعاليت ميكروبى

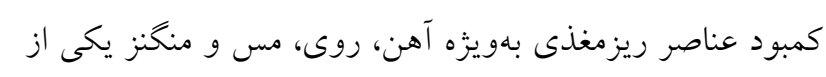

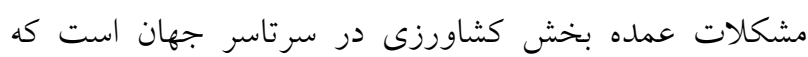

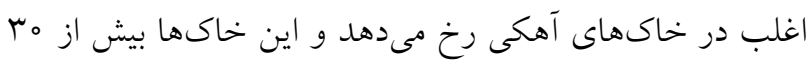

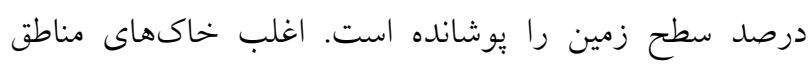

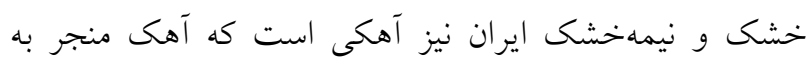

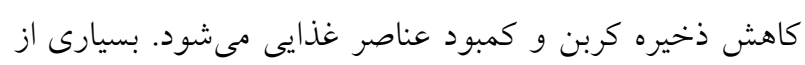

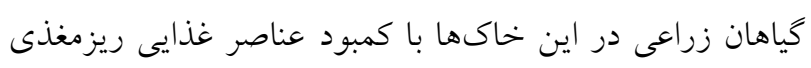

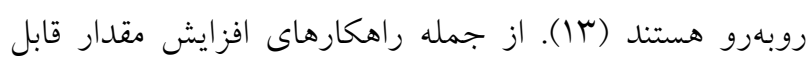

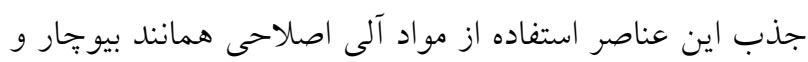
كمبوست حاصل از بقاياى هرس درختان ميوه است. تأثيرات بيو:جار در مقابل كميوست در خاك بسيار متفاوت است. بيوزيار

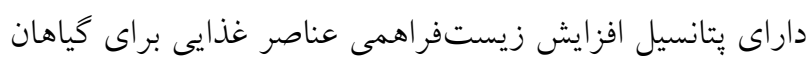

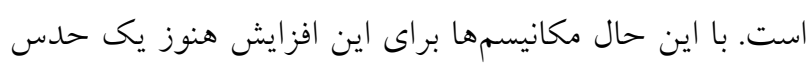

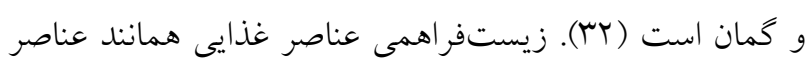
ريزمغذى در خاى و تأثير آنها بر رشد و و عملكرد كياهن عاصنان

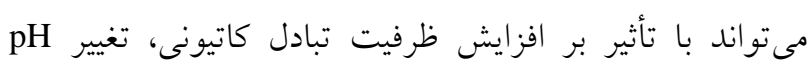

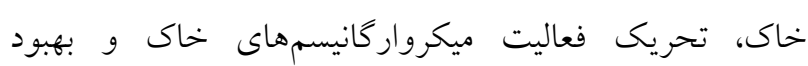
ويزگى هاى كيفى خاى يا مشاركت و كمكى مستقيم عناصر

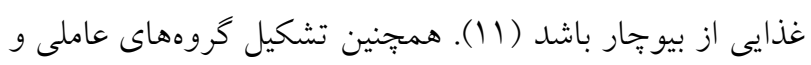

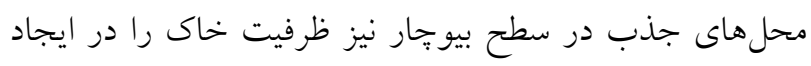

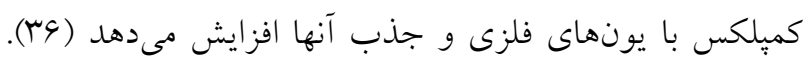

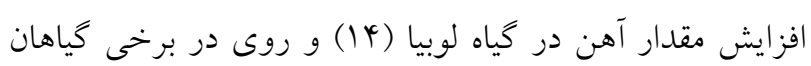

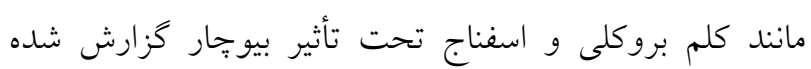

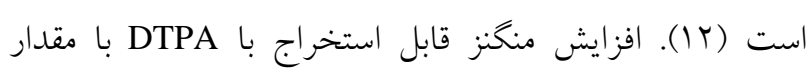

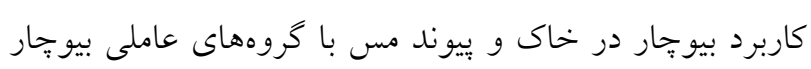

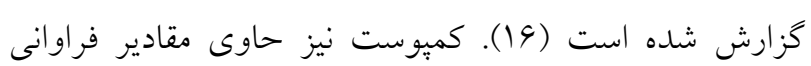

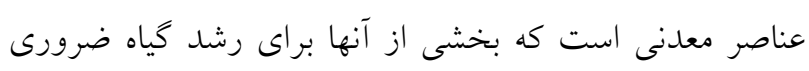

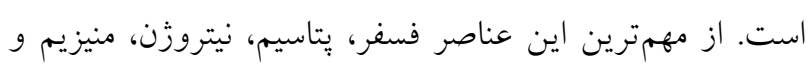

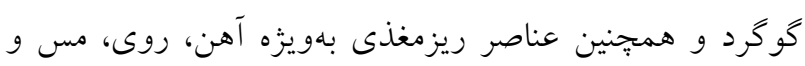

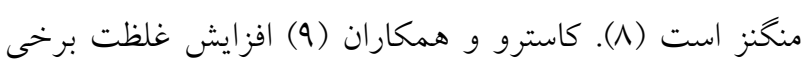

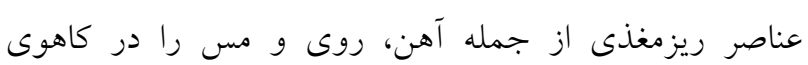




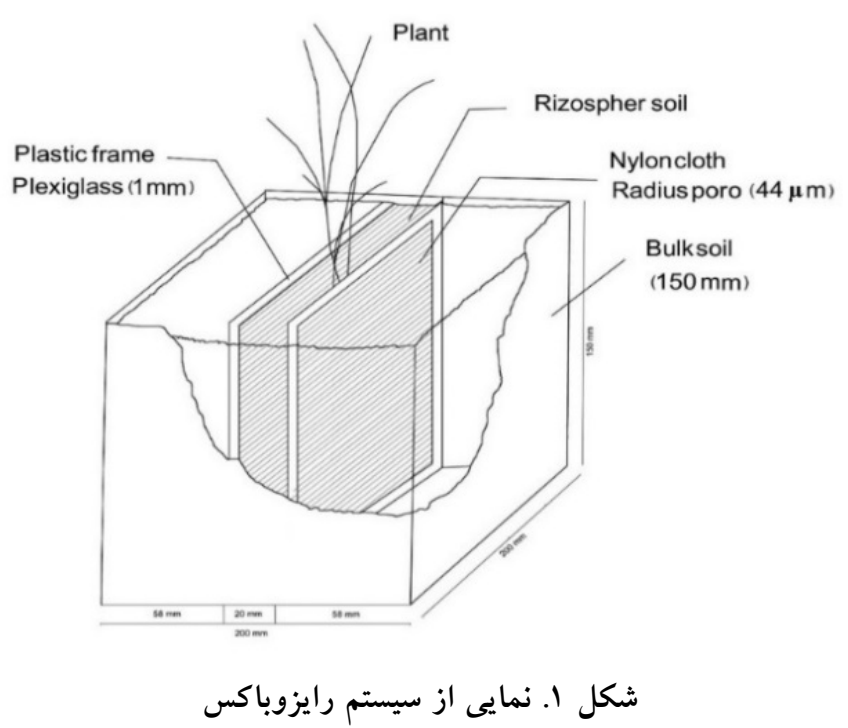

راكتور (استوانه فلزى به قطر لو ارتفاع الس سانتىمتر) و سِّ

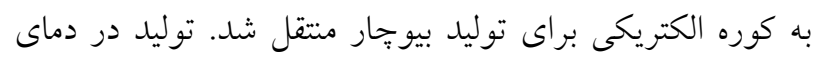

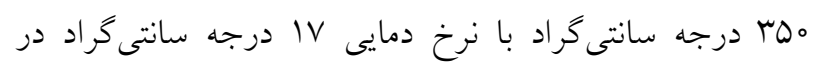

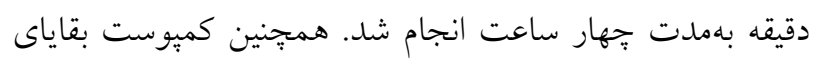
هرس از كلخانه تحقيقاتى كروه علوم خاك دانشخاه اروميه تهيه

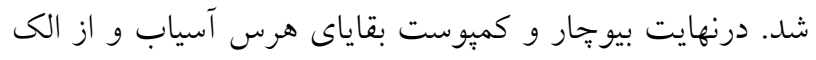

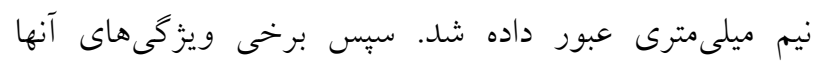

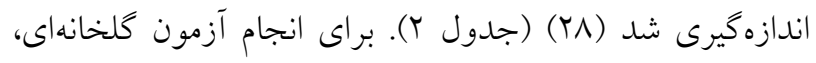

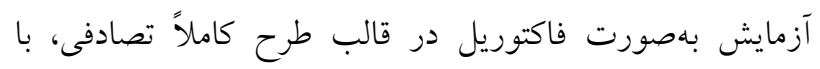

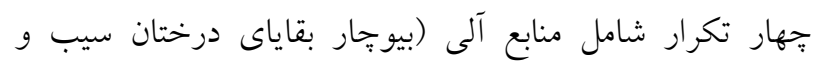

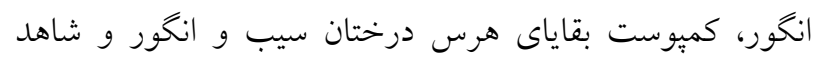

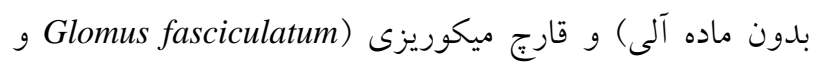

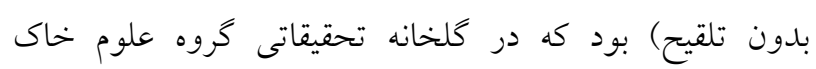

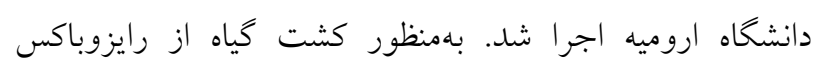

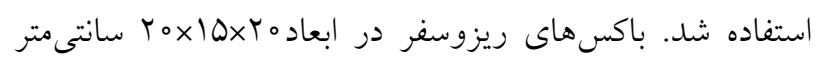

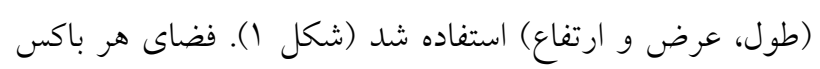

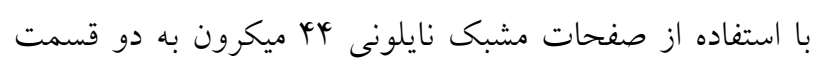

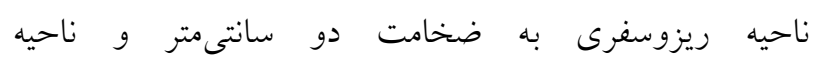

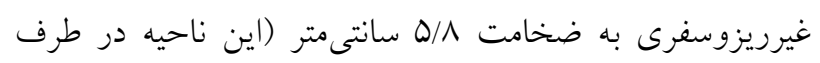

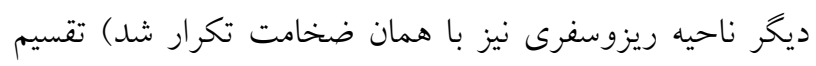

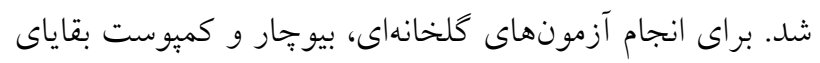

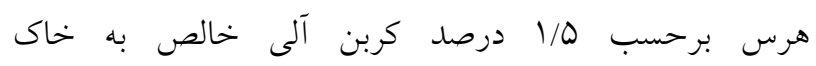

منشأ مى گيرد، تأثير گذار بوده و نتيجه اصلى تشكيل و ايفاى

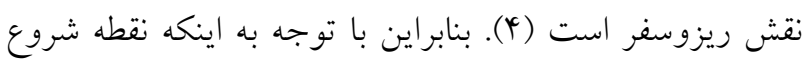
و مسير اصلى عناصر غذايى منطقه ريزوسفر است. بنابراين

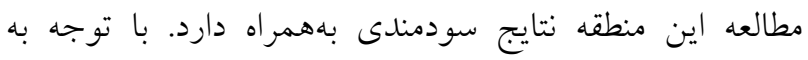
اهميت استراتزيك كُندم كه نقش مهمى در تغذيه مردم در ايران

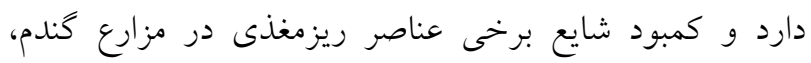

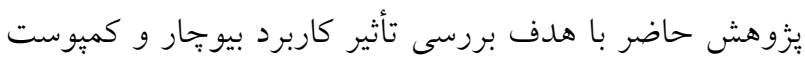

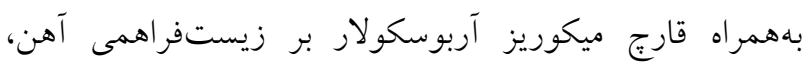

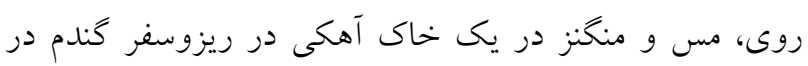

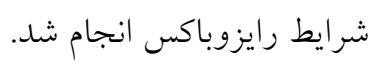

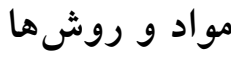

براى انجام اين يُزوهش، خاك غير زراعى مورد استفاده از

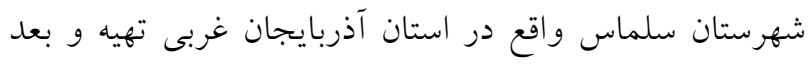
از هوا خشك كردن از غربال دو ميلىمترى عبور داده شد.

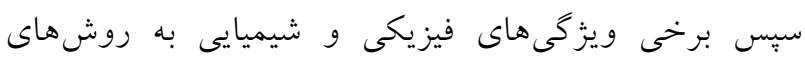

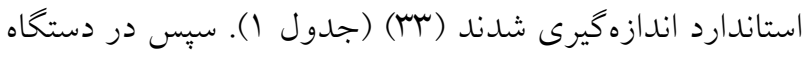

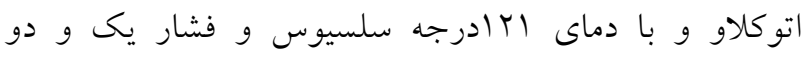
اتمسفر بهمدت دو ساعت استريل شدند. بقاياى هرس درختان

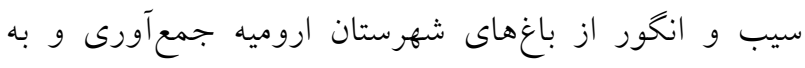

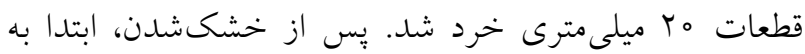




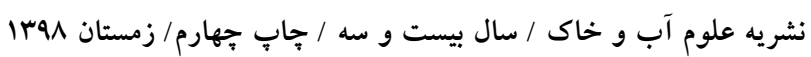

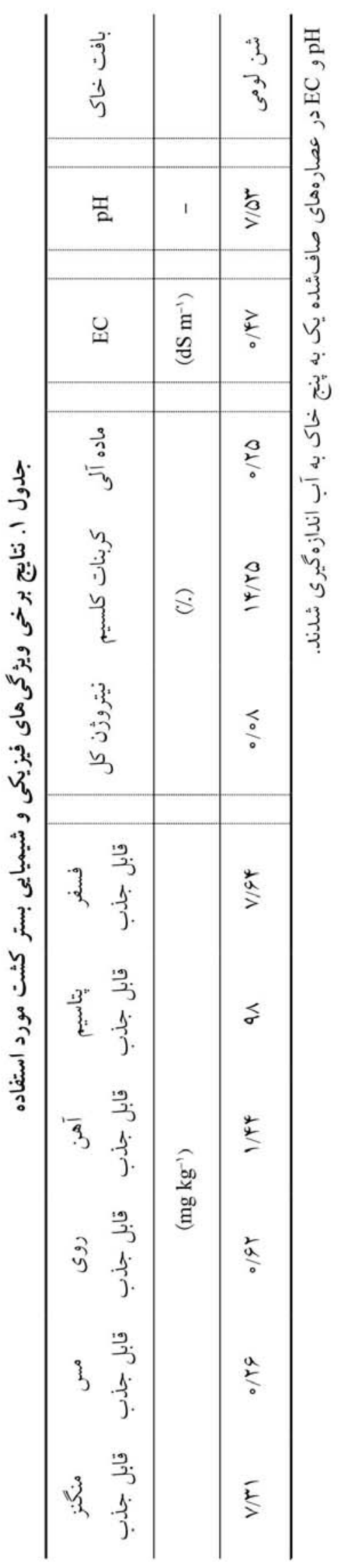




\begin{tabular}{|c|c|c|}
\hline كميوست بقاياى هرس سيب و انخور & بيوجار بقاياى هرس سيب و انگور & ويزگ گىهاى مورد مطالعه \\
\hline$V / \circ D$ & $V / r q$ & $\mathrm{pH}$ \\
\hline IV/AV & $\circ / \circ \wedge$ & $\left(\mathrm{dS} \mathrm{m}^{-1}\right) \mathrm{EC}$ \\
\hline$r \circ / \circ r$ & GV/Dr & كربن (٪) كر) \\
\hline T/VT & $\circ / D Y$ & 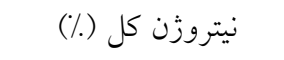 \\
\hline$V / 9 T$ & $1119 / 29$ & $\mathrm{C} / \mathrm{N}$ \\
\hline ITV/A & $\mu \circ \mu / \Psi$ & آهن (mg kg-1) \\
\hline 100 & $\varphi \circ / \Lambda$ & روى (mg kg \\
\hline$\Delta q / 9 Y$ & $Y Q / \circ H$ & مس (mg kg-1) \\
\hline$\mu q 4 / r_{0}$ & $9 / / \wedge \circ$ & منخنز (mg kg-1) \\
\hline
\end{tabular}

و pH در عصاره صافشده l به ه إبيو جار به آب و در كميوست در عصاره صافشده ابه ه كميوست به آب اندازه خيرى شدند.

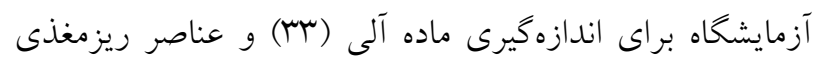

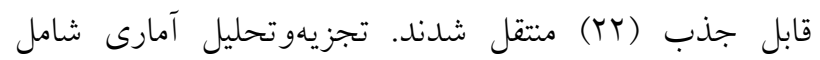
تجزيه واريانس و مقايسه ميانخين دادهها با استفاده از آزمون

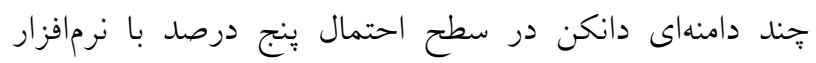

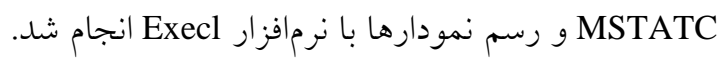

\section{بحث و نتايج} جدول تجزيه واريانس تأثير تيمارهاى مختلف منابع آلى و

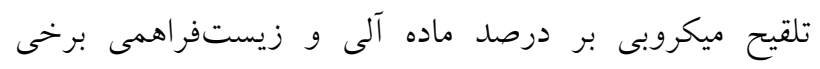

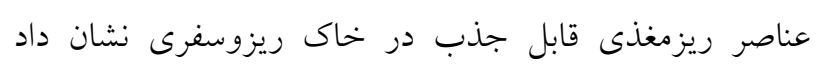

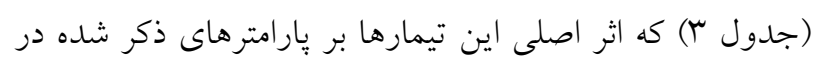

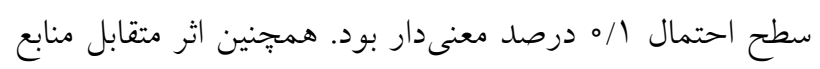

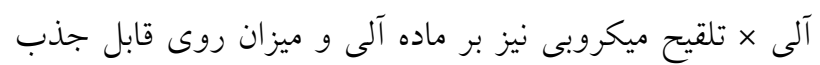

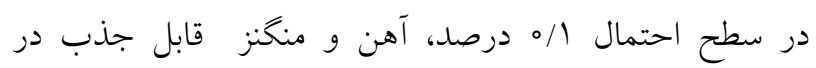
سطح احتمال يك درصد و نيز مس قابل جذب در در سطح احتمال ينج درصد در خاك ريزوسفرى معنى دار بودند.

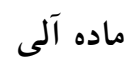
بهطور كلى افزودن مواد آلى درصد ماده آلى ريزوسفر را

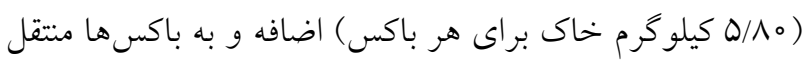

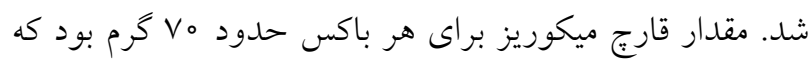

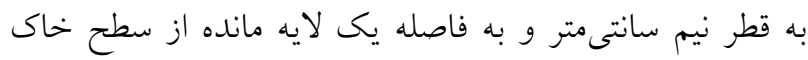

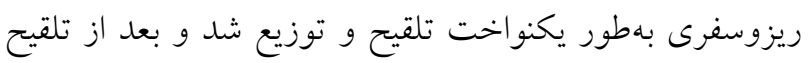

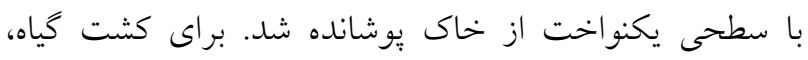

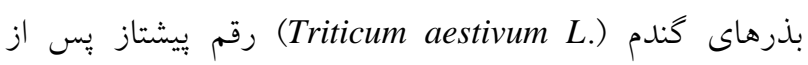

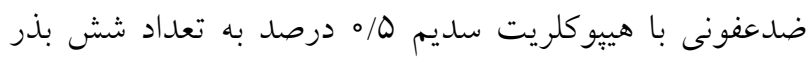
در قسمت ريزوسفرى رايزوباكسها كشت شدند. بِ إن از جوانه

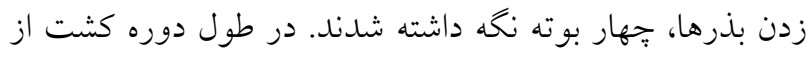

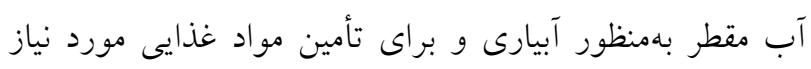

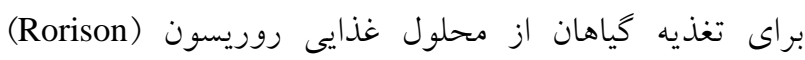

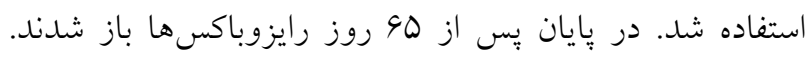

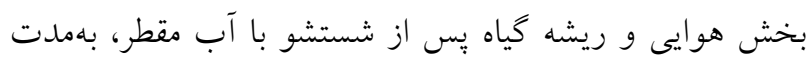

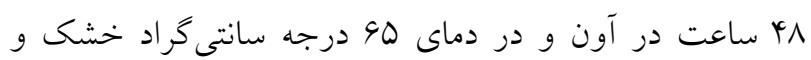

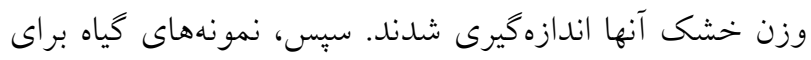
تعيين عناصر ريزمغذى آسياب شدند و آهن، روى، مس و و

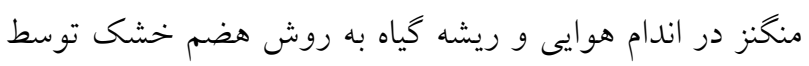

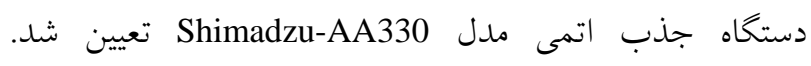
خاكهاى ناحيه ريزوسفرى هر تيمار خشك شدند و و به به 
جدول r. نتايج تجزيه واريانس منابع آلى و تلقيح ميكروبى بر ماده آلى و عناصر ريزمغذى قابل جذب در خاك ريزوسفرى

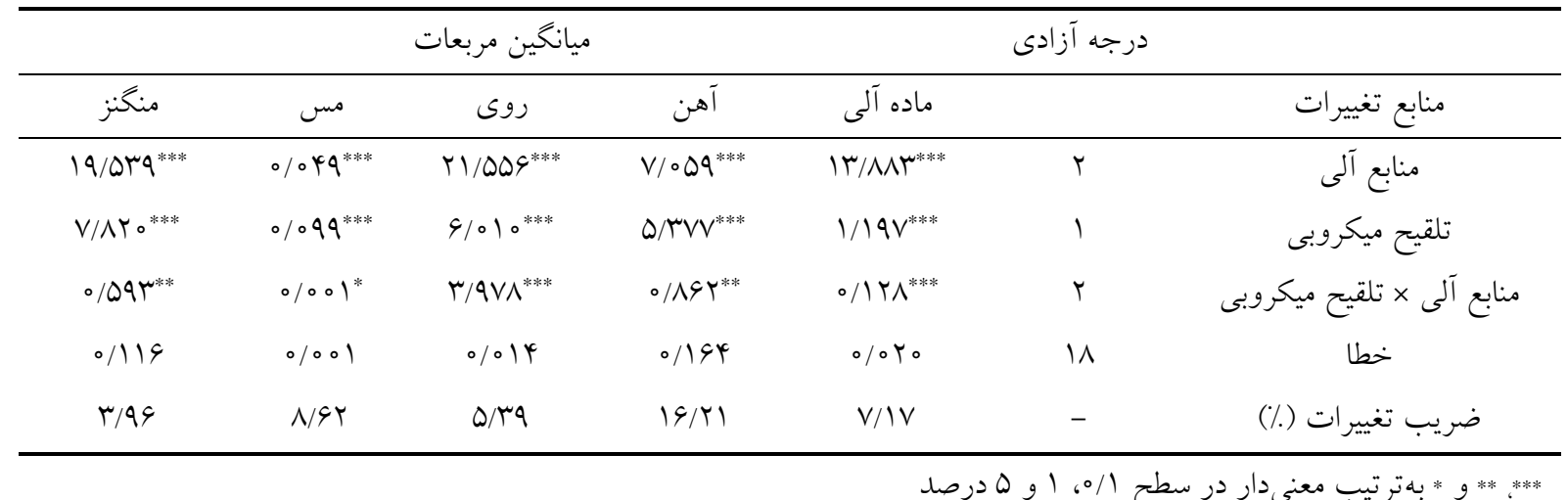

جدول f. نتايج مقايسه ميانگين اثر متقابل منابع آلى و تلقيح ميكروبى بر ماده آلى و عناصر ريزمغذى قابل جذب در خاك ريزوسفرى

\begin{tabular}{|c|c|c|c|c|c|c|}
\hline منكنز & مس & روى & آهن & ماده آلى & & \\
\hline & $\left(\mathrm{mg} \mathrm{kg}^{-1}\right)$ & & & $(\%)$ & منابع آلى & تلقيح ميكروبى \\
\hline $10 / 90^{a}$ & $\circ / \Delta r^{a}$ & $1 / 49^{c}$ & $r / 9 q^{a}$ & $1 / v 9^{c}$ & بيو جار & \\
\hline $9 / Y^{4 b}$ & $\bullet / \Delta V^{a}$ & $\left.\Delta / \Psi^{a}\right)^{a}$ & $r / T \Delta^{b}$ & $r / v Y^{a}$ & كميوست & ميكوريز \\
\hline $\mathrm{V} / \mathrm{N}^{\mathrm{d}}$ & $0 / 41^{b}$ & $1 / r^{\mathrm{d}}$ & $9 \times 1^{d}$ & - /Aqe & شاهد & \\
\hline$৭ / / \wedge^{b}$ & $0 / K^{b}$ & $1 / \mathrm{rVd}^{\mathrm{cd}}$ & $T / T q^{C}$ & $1 / 4 q^{d}$ & بيو جار & \\
\hline$N / \mu Y c$ & $0 / 4 k b$ & $r / N \wedge^{b}$ & $r /\left.9\right|^{\mathrm{C}}$ & $r / \circ r^{b}$ & كميوست & بدون تلقيح \\
\hline $9 / 0 \wedge^{\mathrm{e}}$ & $\circ / q^{c}$ & $\circ / 9 \wedge^{e}$ & l/IVe & $0 / 9 \mathrm{~V}^{\mathrm{f}}$ & شاهد & \\
\hline
\end{tabular}

بخش ديخر ماده آلى باقىمانده در تعامل با هيف، ساختمان

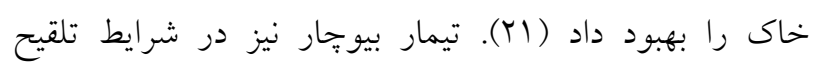

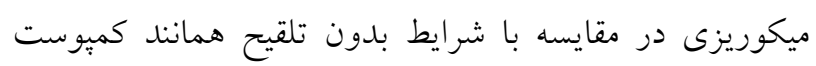

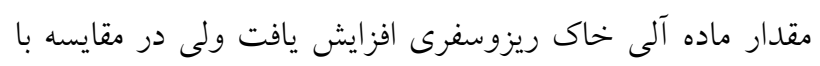

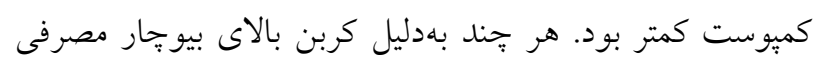

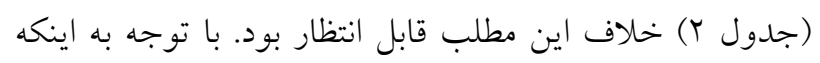

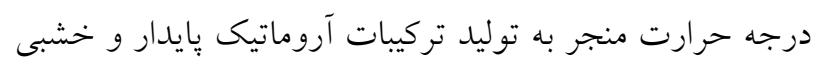

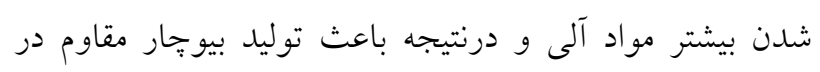

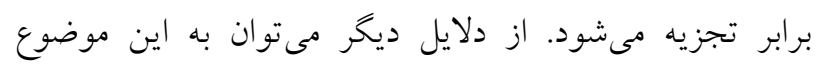

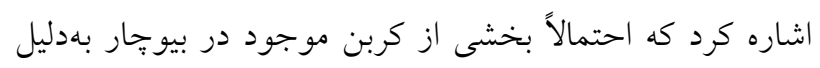

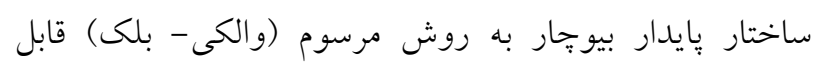

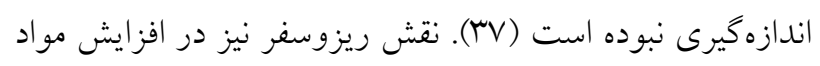

افزايش داده است (جدول †). همانطور كه مقايسه ميانخين دادهها نشان مىدهد (جدول \&) تلقيح ميكوريزى نيز در مقايسه

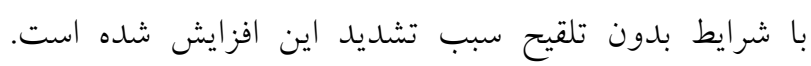

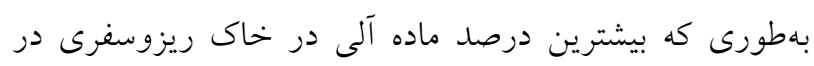

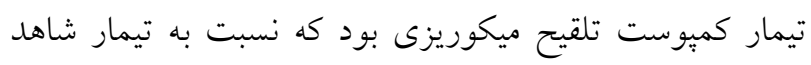

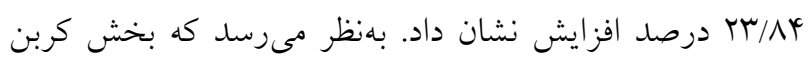

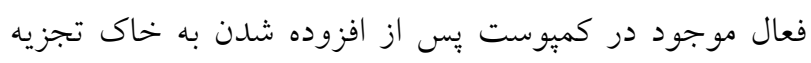
شده و همجنين بخشى از كربن موجود در اين كود به ذخاير

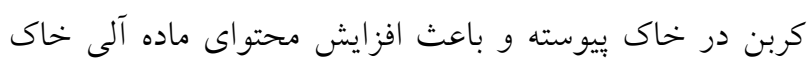

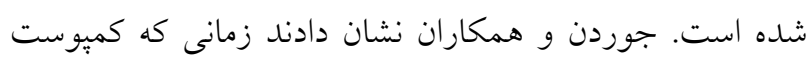

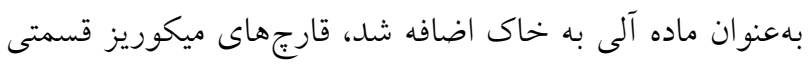

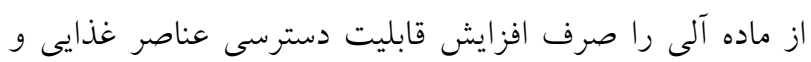


افزايش در روى و مس قابل جذب در خاك و البته در شرايط

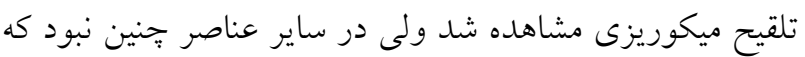

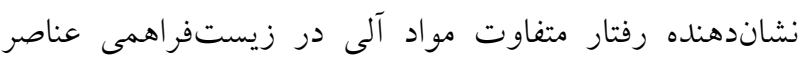
است كه سبب شده بيوجار و كميوست رفتارهاى متفاوتى بر زيستفراهمى عناصر داشته باشند. مشاهده شده است كه اضافه

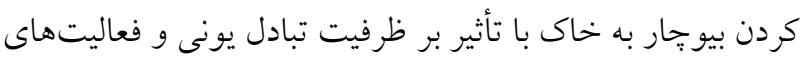
ميكروبى بر قابليت استفاده يونهاى غذايى مؤثر است (r). تشكيل كروههاى عاملى و محل هاى جذب در سطح بيوجار نيز ظرفيت خاك را در ايجاد كميلكس با يونهاى فلزى و جذب آنها را افزايش مىدهد (4)). بيوجار تهيه شده از جوب مىتواند فعاليتهاى ميكروبى در خاك را با فراهمى كردن زيستخاه،

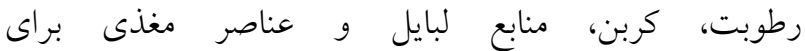
ميكروار كانيسمها افزايش دهد. بيوخارها داراى شكل نامنظم با ساختار متخلخل هستند. ساختار متخلخل بيو:جار، سطوح ويزه بالا و توانايى آن براى جذب مواد آلى محلول، كازها و مواد

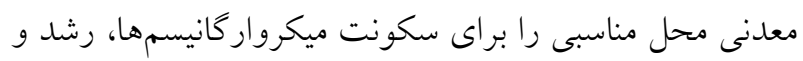
تكثير آنها بهويزه قارجهاى ميكوريز آربوسكولار فراهم مى مئى آورد.

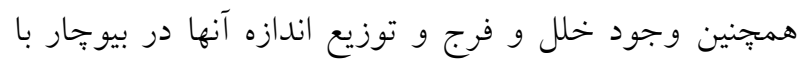

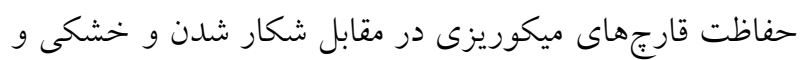

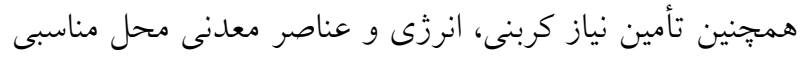

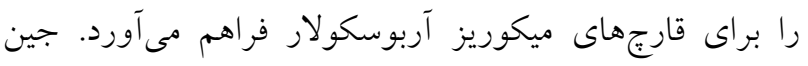

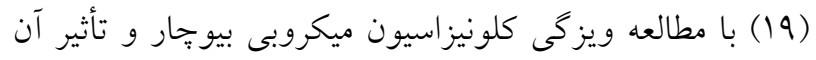

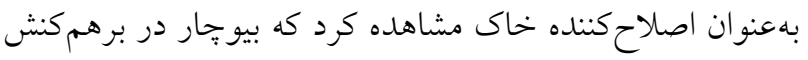

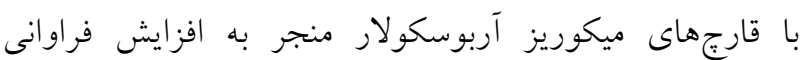

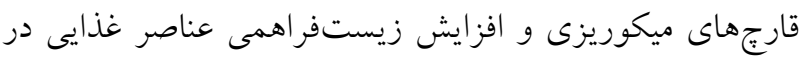

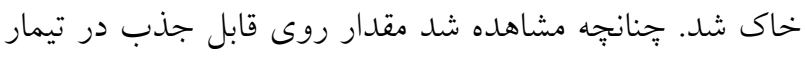
بيوجار تلقيح نسبت به تيمار بدون تلقيح تفاوت معنىدارى نشان نداد. دلايل مختلفى براى كاهش مقدار روى قابل جذب با باليا

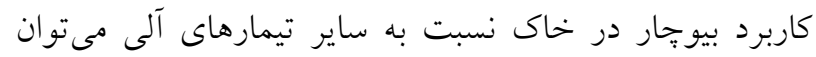
بيان كرد. كاهش زيستفراهمى روى در خاك در اثر كاربرد بيوجار مىتواند ناشى از رشد بيشتر كياه و در نتيجه جذب بيشتر روى از خاك باشد. اثر رقت، جذب يونهاى فلزى روى
آلى نيز تأثير كذار است زيرا سرعت ورود مواد آلى در ريزوسفر

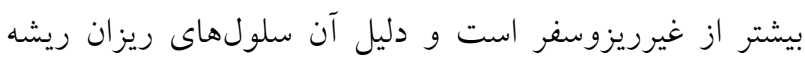

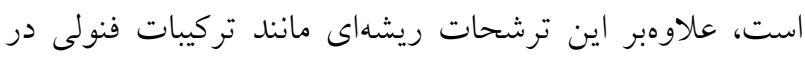
ريزوسفر بهعنوان محرى رشد ميكروبى در خاى ريزوسفرى

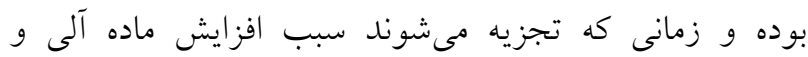
عناصر غذايى غذايى در خاك مىشوند. ميكروراكانيسمهاى

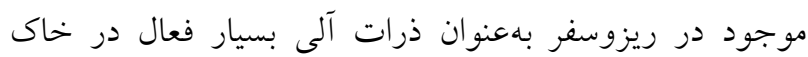
بهشمار مىروند كه داراى سطحى فعال و باردار و نيز توانايى توليد و ترشح بسيارى از تركيبات آلى و كربوهيدراتها فها را داردا

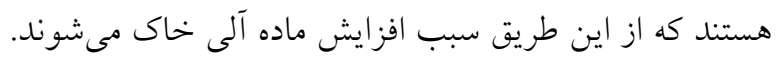

قابليت زيستفراهمى عناصر ريزمغذى قابل جذب در خاك ريزوسفرى

اثر منابع آلى و تلقيح ميكوربزى نشان داد كه افزودن مواد آلى تئل

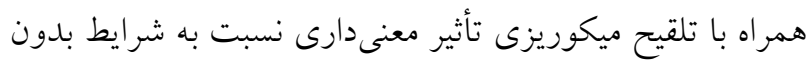

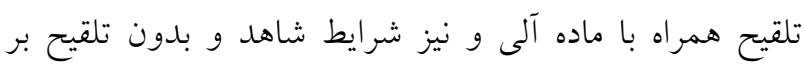

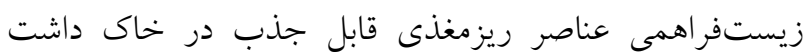
(جدول \&). بهطورى كه در شرايط تلقيح ميكوريزى، حضور

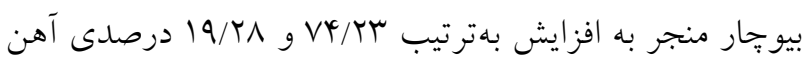
و منكنز نسبت به شرايط بدون تلقيح شد. در شرايط بدون بدرن

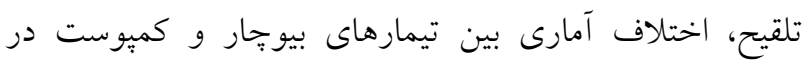
زيستفراهمى آهن قابل جذب مشاهده نشد هر קند هر دو تيمار نسبت به تيمار شاهد در هر دو سطح تلقيح ميكروبى ندابل افزايش نشان دادند. همجنين بالاترين ميزان روى و مس قابل جذب نيز مربوط به تيمار تلقيح ميكوريزى كميوست بود كه

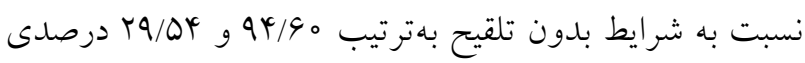

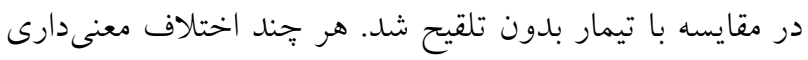

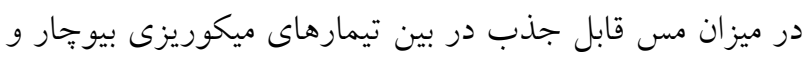

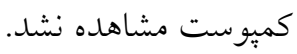
با توجه به بالا بودن ميزان عناصر ريزمغذى در كميوست

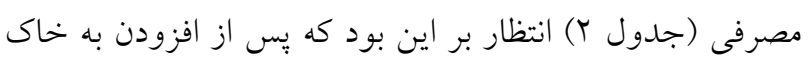

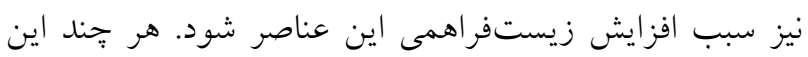


دماهاى بالاتر باشد. نواى و همكاران (YV) همجنين بيان كردند

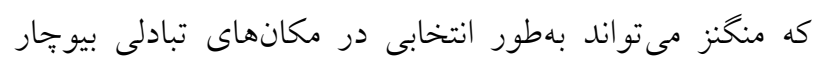
يوست كردو جذب شود.

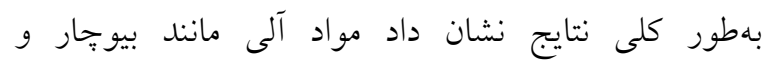
كميوست در حضور قارجهاى ميكوريز سبب افزايش زيستفراهمى عناصر ريزمغذى شدند. مواد آلى كربن مورد نياز قارجهاى ميكوريزى را فراهم كرده در نتيجه اين قارجها باسيا كسترش هيفهاى خود در خاك منجر به افزايش سطح ريشه و كاهش فاصله انتشار شده، در نتيجه منجر به افزايش زيست

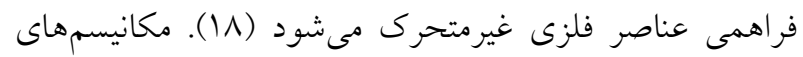

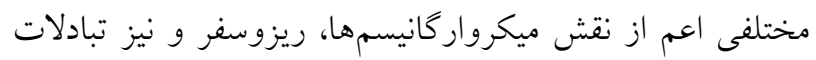

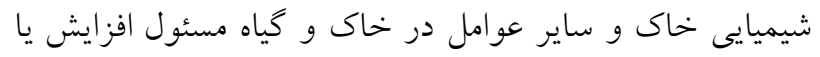
كاهش نخهارى عناصر غذايى در خاك است است. افزايش

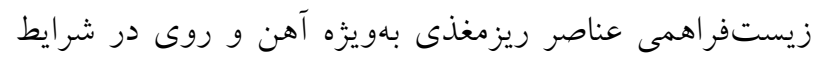

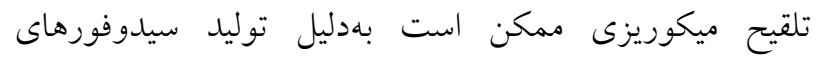

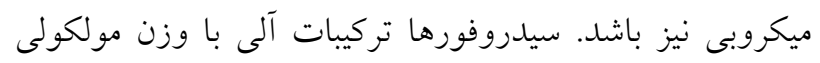

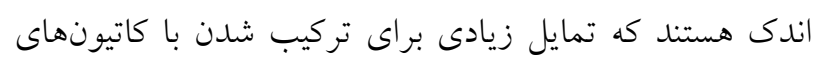

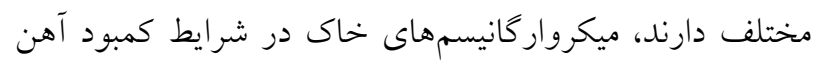

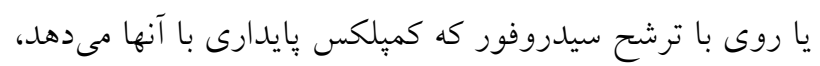
آنها را بهصورت محلول و قابل دسترس در مى آورند (Y) (Y).

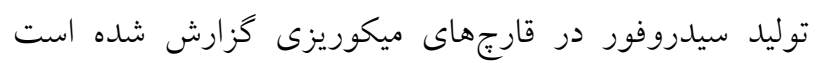

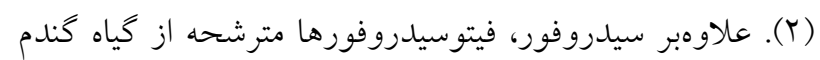

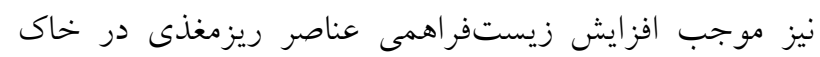

$$
\text { ريزوسفرى مىشوند (T)) (19). }
$$

\section{ميزان عناصر ريزمغذى جذب شده گياه گندم}

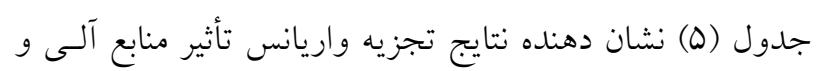

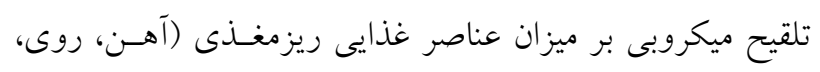

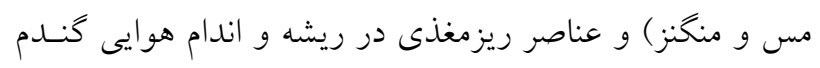

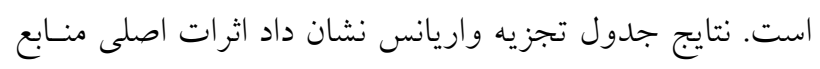

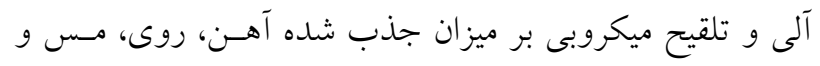

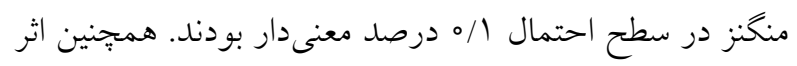

سطح ذرات بيو حار و غيرمتحرى شدن آنها نيز مىتواند موجب

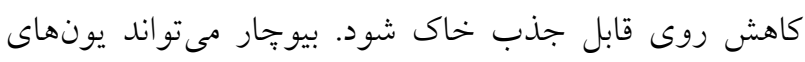

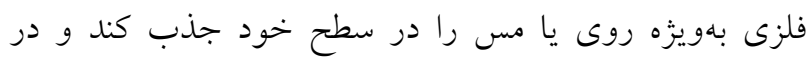

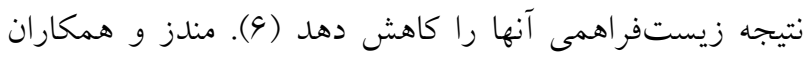

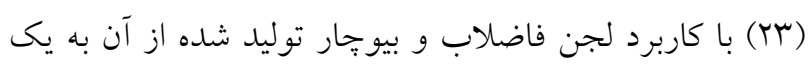

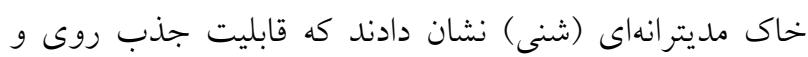

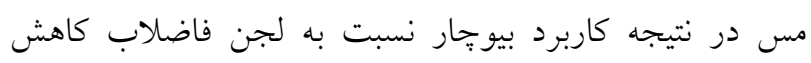

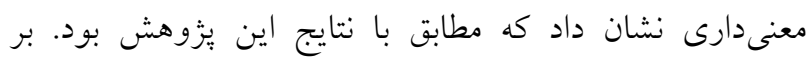

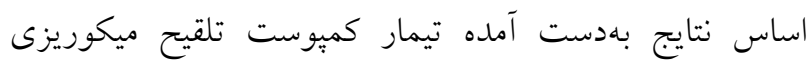
بيشترين تأثير را در مقدار روى و مس زيست فراهم در خاك

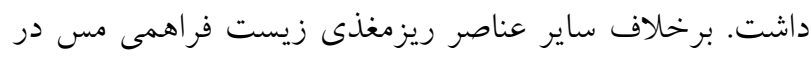

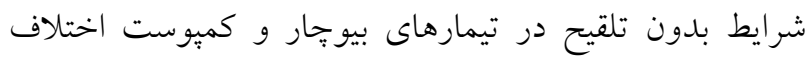

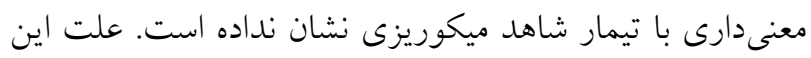

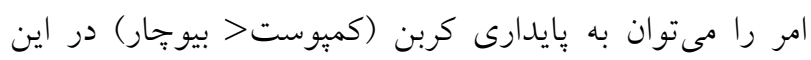

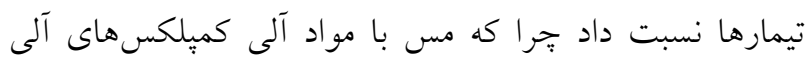

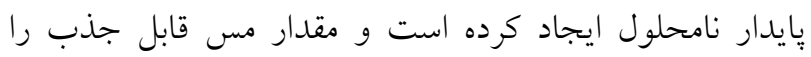

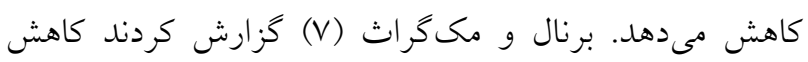
بخش زيستفراهم فلزات ريزمغذى بهويزه مس در ريز بروسفر ممكن است بهعلت تشكيل كميلكس با تركيبات آلى ريزوسفر

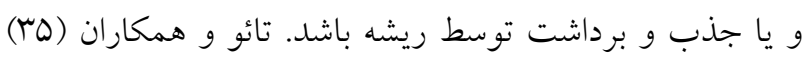

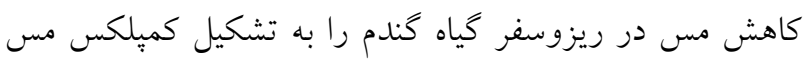

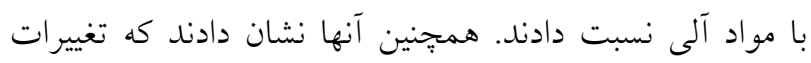

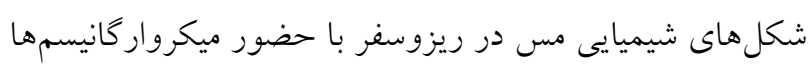

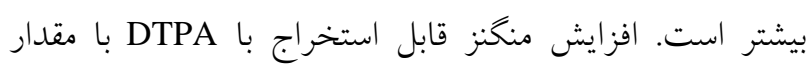

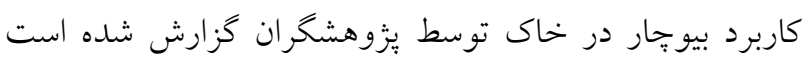

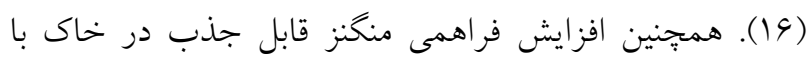
كاربرد بيوجار به بيوجار تهيه شده در دماى كمتر نسبت دادئ داده

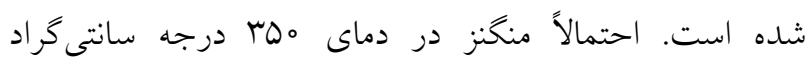

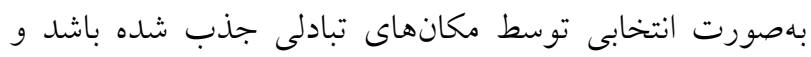

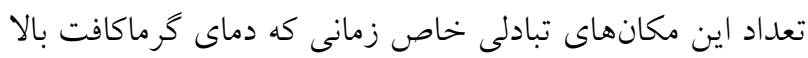

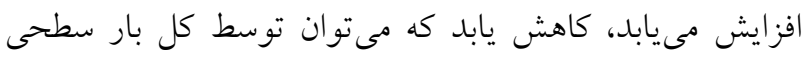

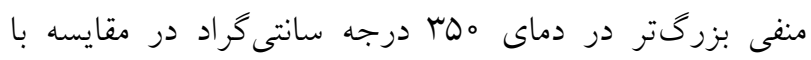




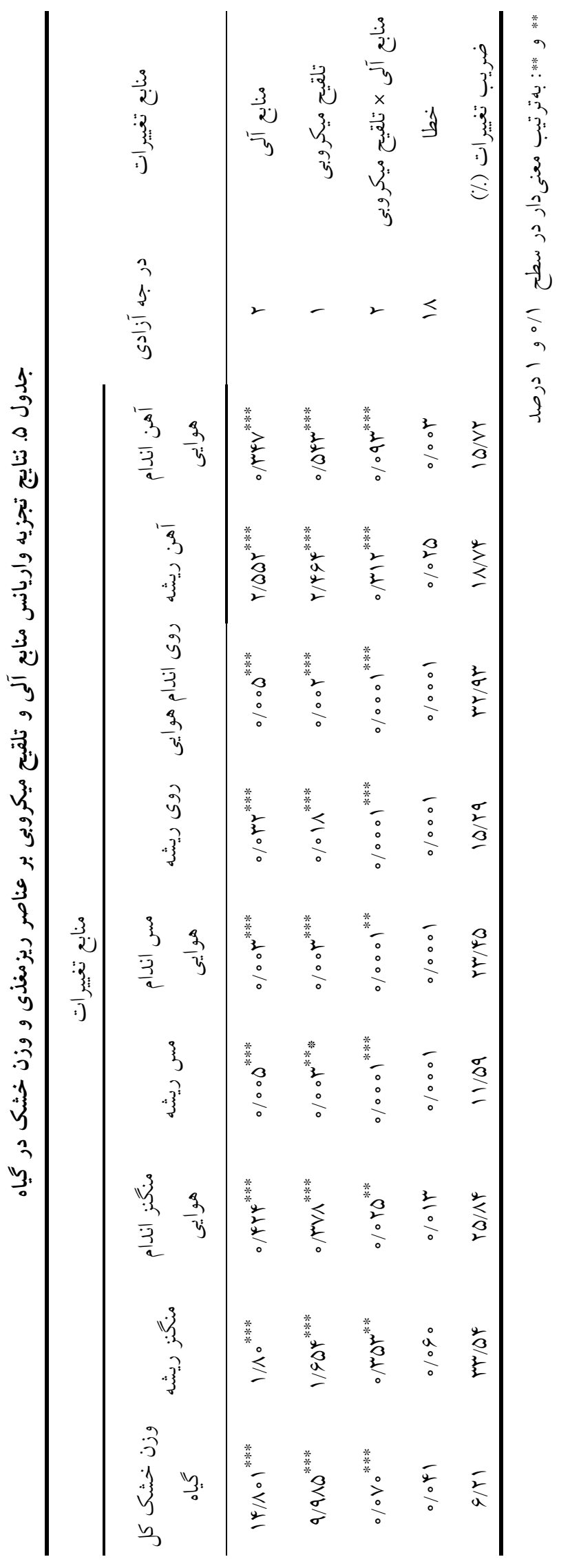


جذب عناصر در گياه تحت تأثير غلظت عناصر در خاك

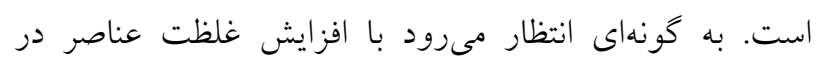

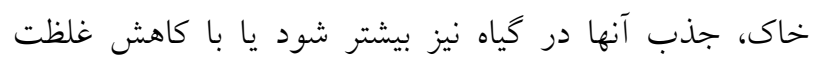
عناصر در خاك جذب بيشترى توسط كياه انجام گرفته باشد باهد

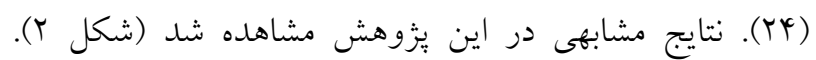

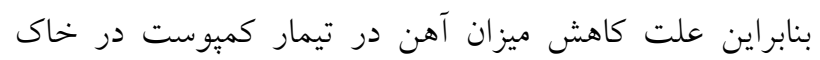
ريزوسفرى جذب بيشتر اين عنصر توسط كياه از ريزوسفر بوده است. كاسترو و همكاران (9) افزايش عناصر ريزمغذى همانند

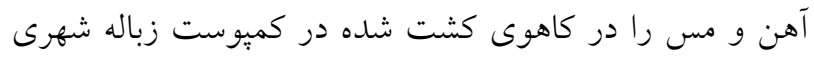
كزارش كردند. آنها علت اين افزايش را محتواى بالاى غلظت

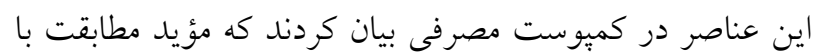

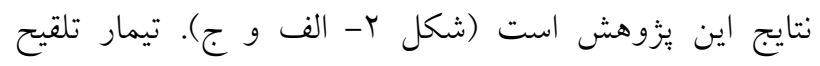

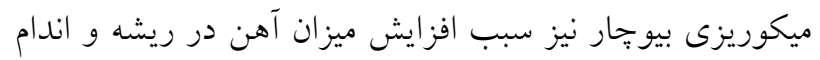

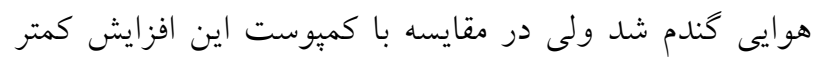

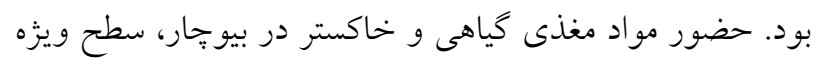

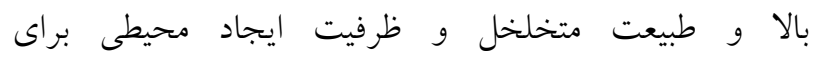

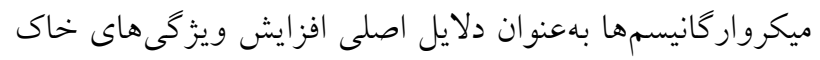
و جذب عناصر غذايى توسط كياه در خاكهاى تحت تيمار

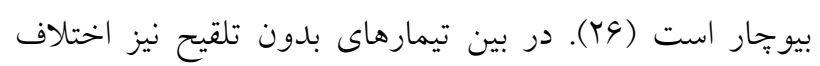

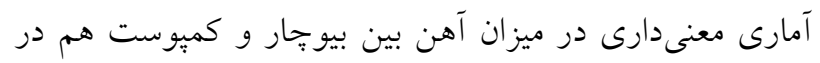

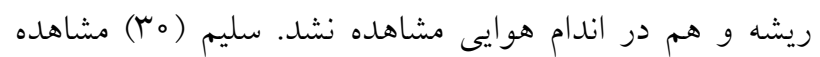

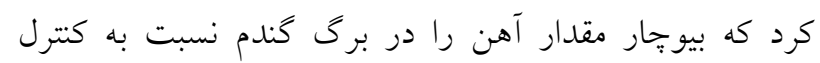

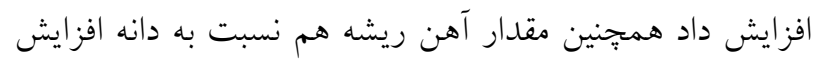

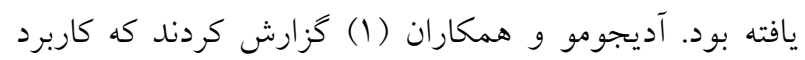

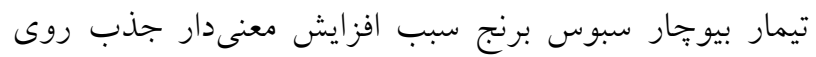

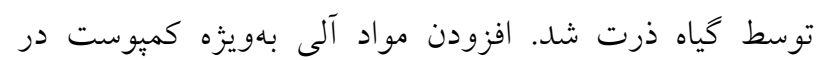

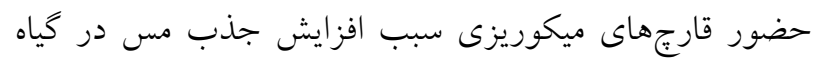
شده كه مىتوان به غلظت مس تحت تأثير اين تيمار اشاره كرد

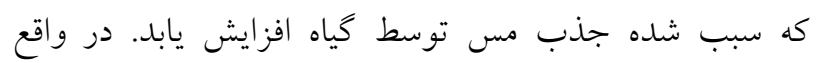

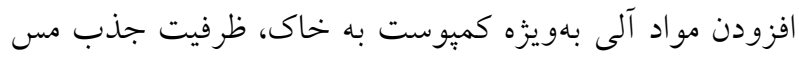

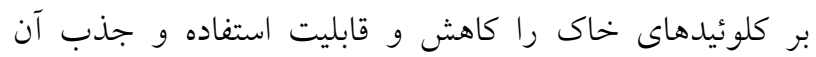

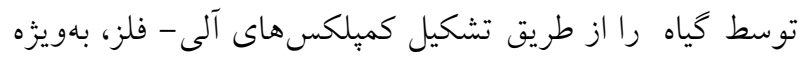

اصلى نوع بيوجار و اثر متقابل نوع × مقدار بيوجار بر مقدار

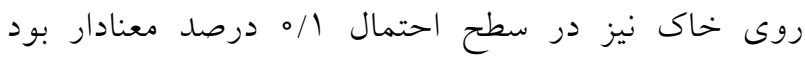
همجنين اثر متقابل منابع آلى × تلقيح ميكروبى بر مئى ميزان

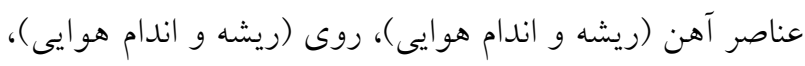

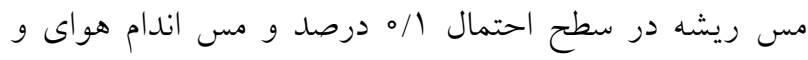
منخنز (ريشه و اندام هوايى) در سطح احتمال ا درصد معنى دار

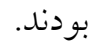
نتايج تجزيه كياه نشان داد كه افزودن مواد آلى بهويزّه كميوست به خاك در حضور قارج ميكوريزى، مقدار آهن اندام هوايى و ريشه را افزايش داد (شكل r- الف). بيشترين ميزان

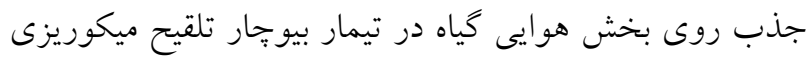

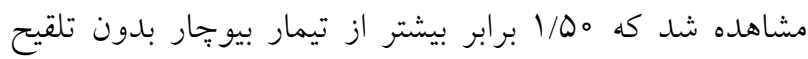

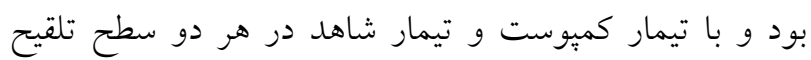
تفاوت معنىدارى از لحاظ آمارى نشان داد (شكل ب- ب). همجنين كاربرد ماده آلى همراه با حضور قارج ميكوريزى تأثير معنى

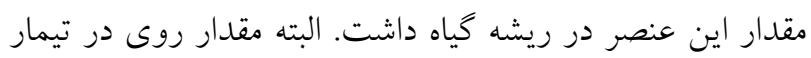
كميوست همراه با تلقيح ميكوريزى در مقايسه با ساير تيمارها

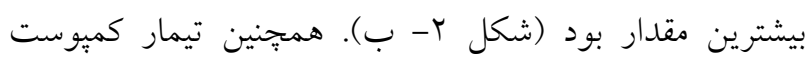

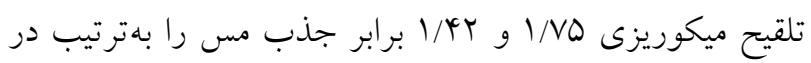

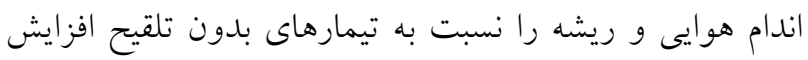

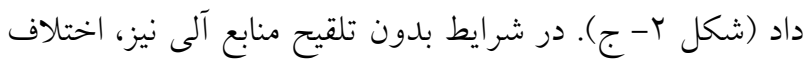

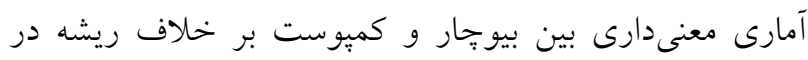
جذب مس مشاهده نشد. مقايسه ميانخين اثر متقابل تلقيح ميكروبى و منابع آلى بيانكر افزايش معنىدار مقدار منكنز كياه

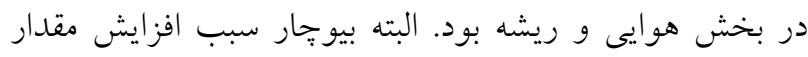

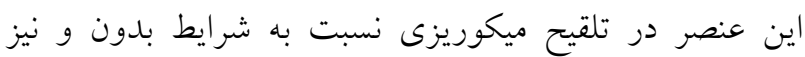

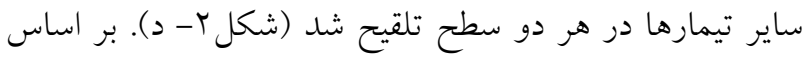

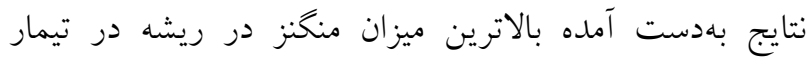
كمبوست مشاهده شد. تيمارهاى بيو:هار و كمبوست اختلاف

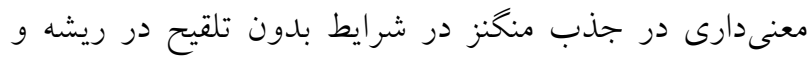

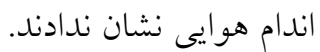


(ب)

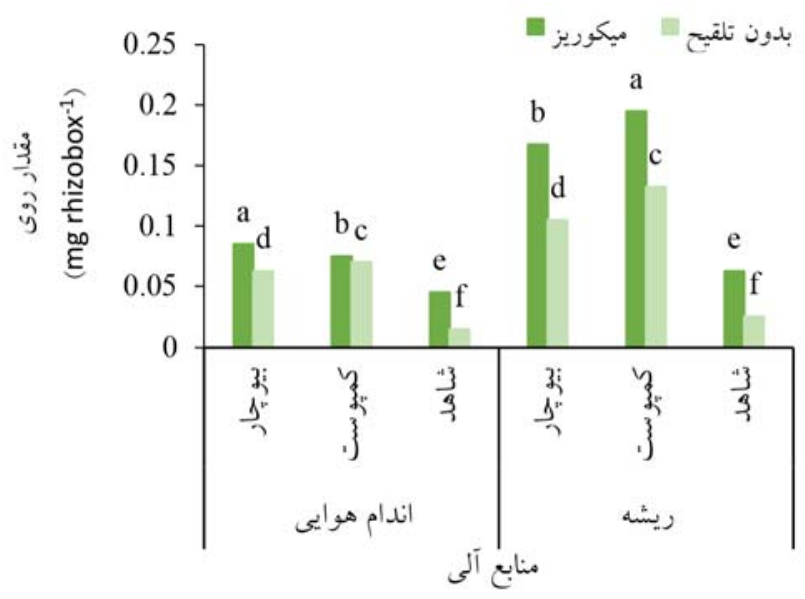

(د)

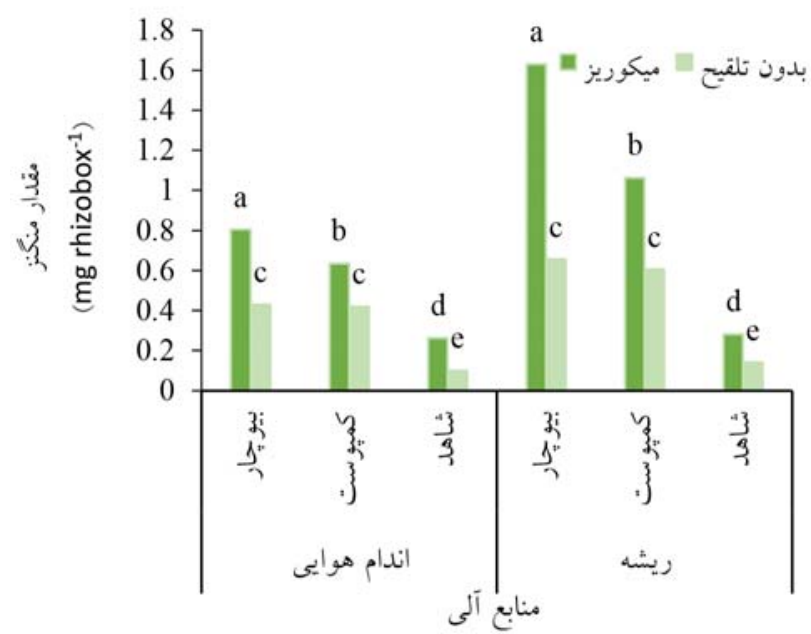

(الف)

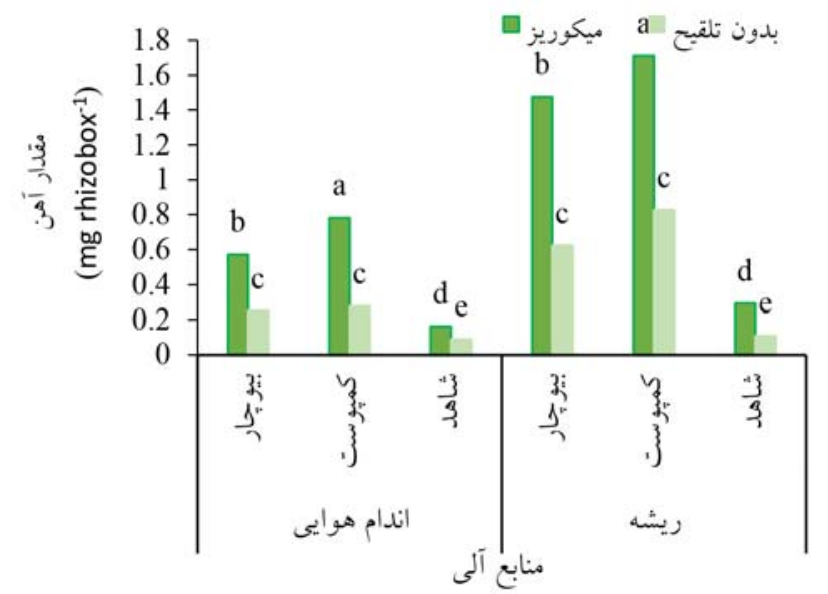

(ج)

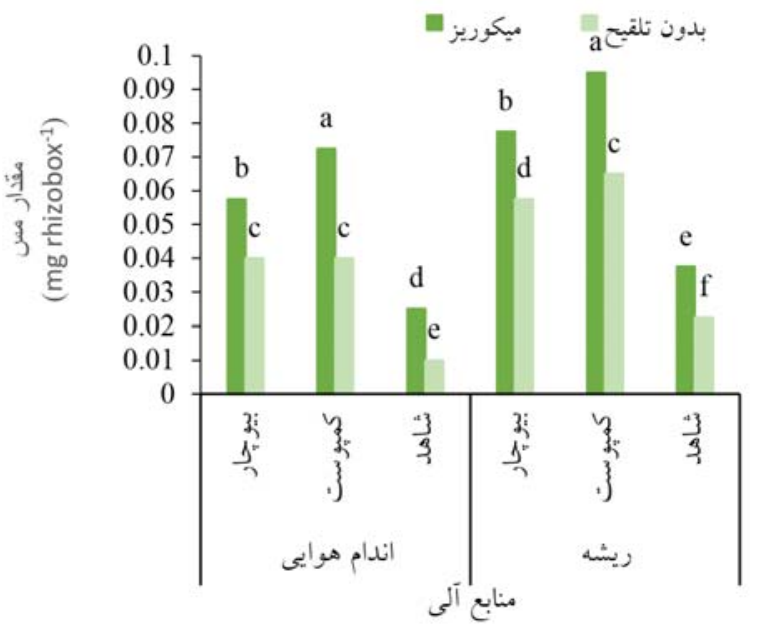

شكل r. مقايسه ميانگين اثر متقابل منابع آلى و تلقيح ميكروبى بر مقدار عناصر ريزمغذى: الف) آهن، ب) روى، ج) مس و د د) منكنز در

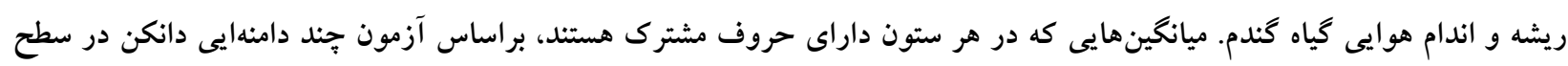
احتمال ينج درصد اختلاف معنىدارى ندارند.

است كه نتيجه كزارش شده مشابه سليم (ro) است. وى نيز با

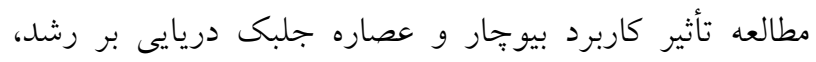

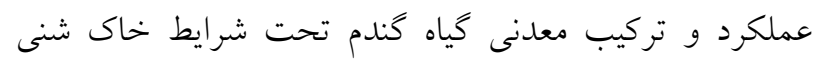

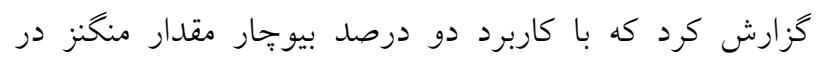

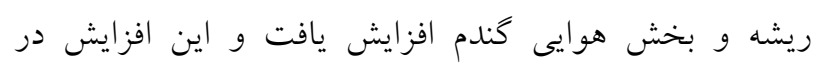
بخش ريشه بيشتر ار اندام هوايى گندم بود.

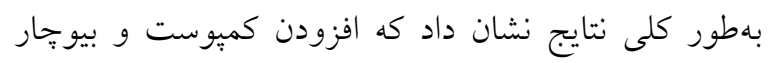

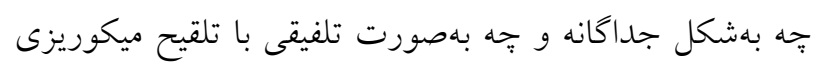

در خاكهاى آهكى افزايش مىدهد. نامكى و همكاران (YO)

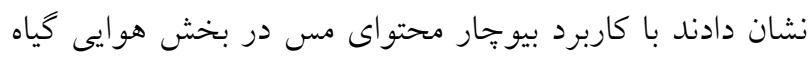

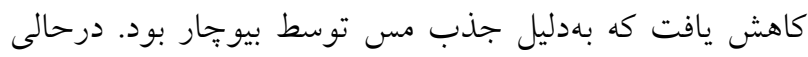
كه ايييوليتو و همكاران (ه) ثابت كردند كه بيوجار مىتواند مس را روى سطح يا رسوب كانىهاى كربنات مس يا اكسيد

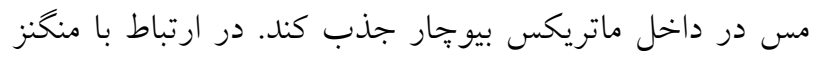
در تيمار تلقيح ميكوريزى كياه نيز مىتوان جنين بيان كرد كه

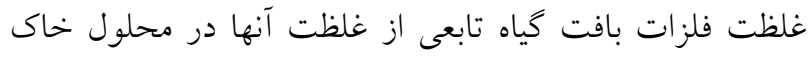




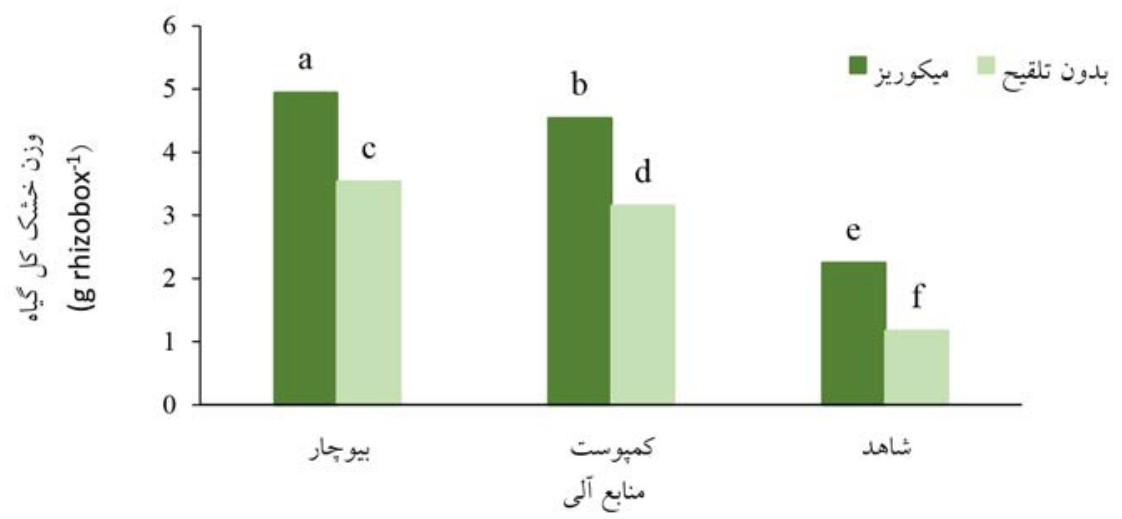

شكل r. مقايسه ميانكين اثر متقابل منابع آلى و تلقيح ميكروبى بر وزن خشك كل گياه. ميانكينهايى كه در هر ستون

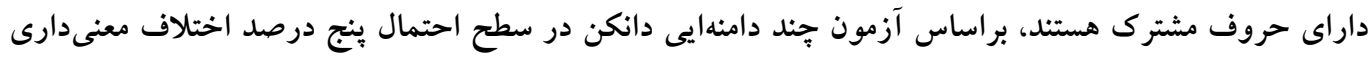
ندارند.

منابع آلى و تلقيح ميكروبى بر وزن خشك كل كياه نسبت به

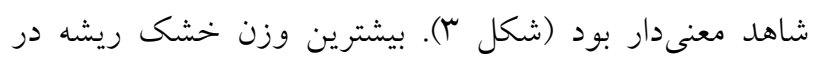

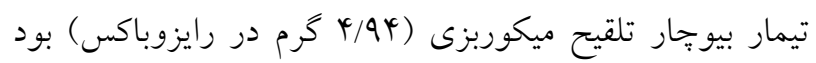
كه اختلاف معنىدارى با ساير تيمارها داشت. كمترين وزن

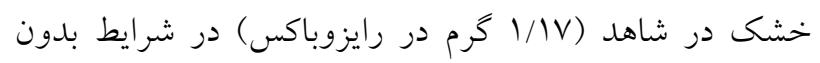
تلقيح بود. تيمار بيو جار در هر دو سطح تلقيح در مقايسه با باهن بيوجار وزن خشى كياه كندم را افزايش داد.

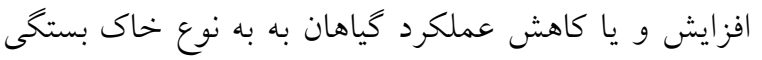

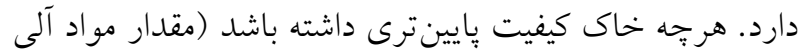
كمتر و ظرفيت پايينتر نخهلارى عناصر غذايى (همانند خاك

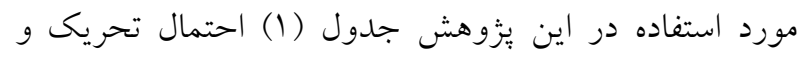
افزايش عملكرد گياه بيشتر است (YN). در بسيارى از مطالعات،

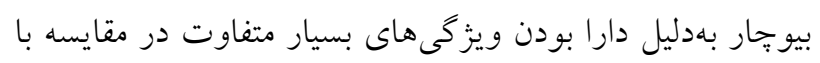

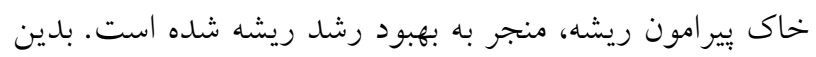

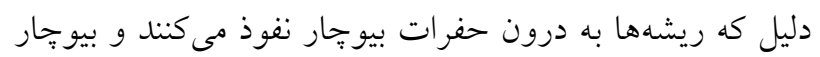

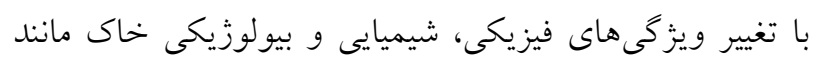

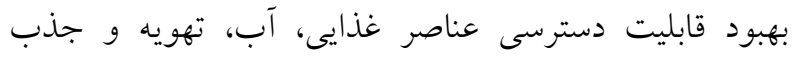

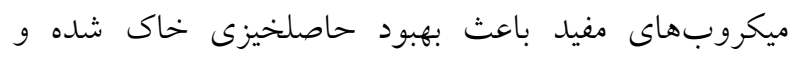

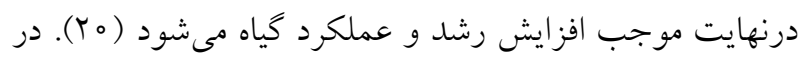

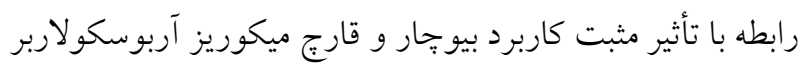

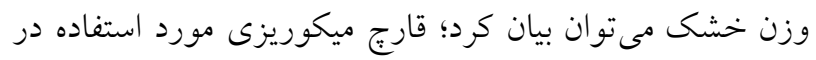

باعث افزايش جذب روى، مس و منگنز در كياه شد و اين افزايش در شرايط تلقيح ميكوريزى بيشتر بود.

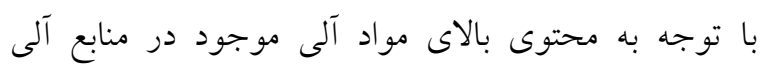

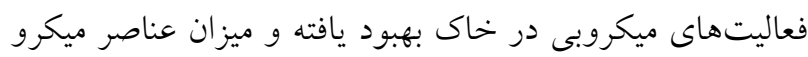

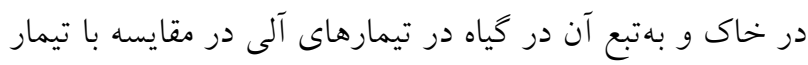

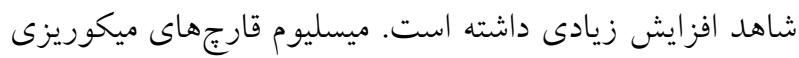

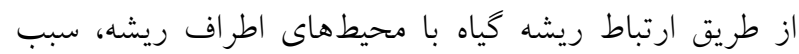
افزايش حجمى از خاك كه در اختيار ريشه كياه است مى شود. اين مسئله سبب بقاى كياه در محيطهايى كه با كمبود آب و

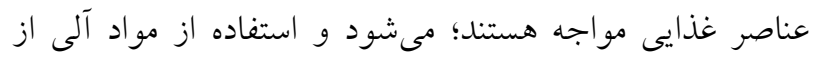

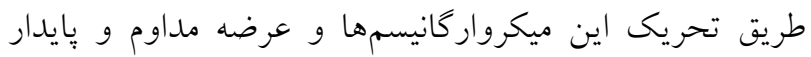

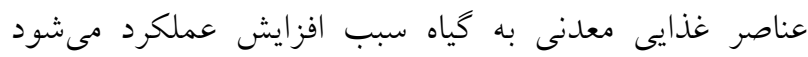

نتايج بهدست آمده از شكل (Y) نشان داد كه مقدار عناصر

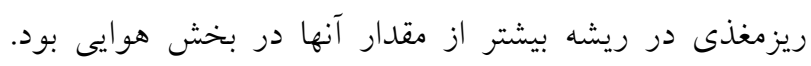

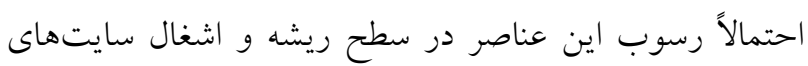
فعال در جذب اين عناصر (ه) باعث شده است كه مقدار آنها

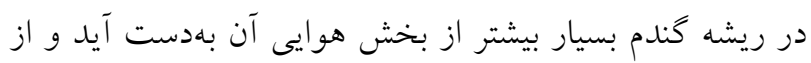

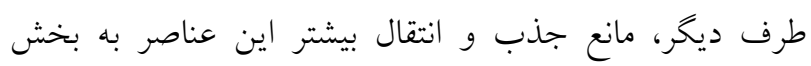
هو ايى گياه كندم شود. بر اساس مقايسه ميانخين دادهها مىتوان اظهار داشت كه اثر 


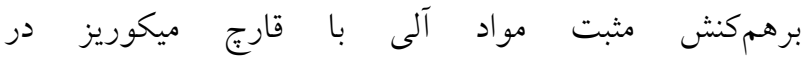

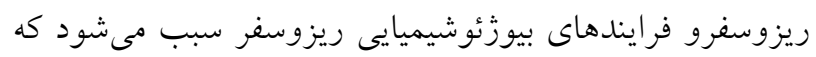

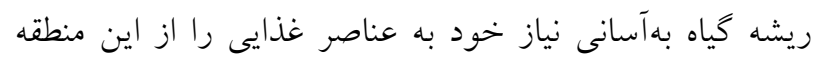

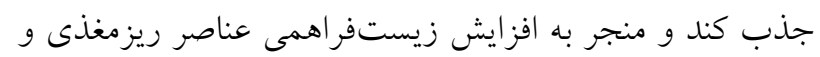

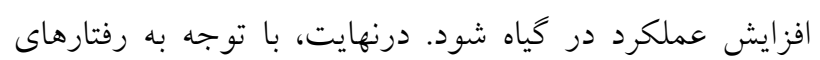

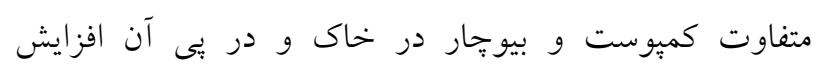

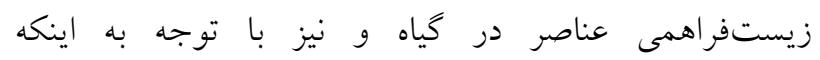

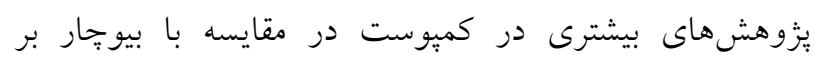

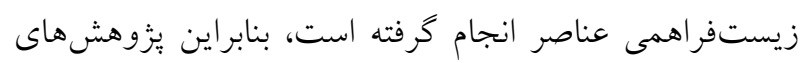

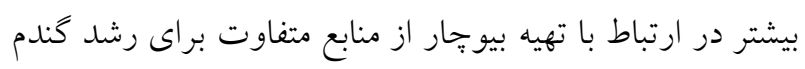

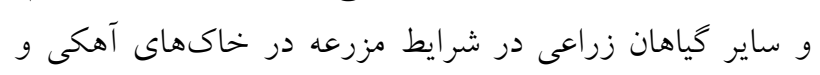

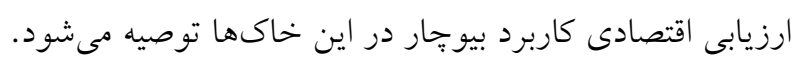

$$
\begin{aligned}
& \text { سياسگزارى } \\
& \text { بخشى از نتايج اين يزوهش در قالب طرح يزوهشى شماره }
\end{aligned}
$$

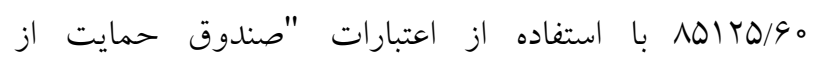

$$
\begin{aligned}
& \text { يُزوهشخران و فناوران كشور" انجام شده است كه بدين وسيله } \\
& \text { تقدير و تشكر مىشود. } \\
& \text { نتيجه گيرى }
\end{aligned}
$$

1. Adejumo, S. A., M. O. Owolabi and I. F. Odesola. 2016. Agro-physiologic effects of compost and biochar produced at different temperatures on growth, photosynthetic pigment and micronutrients uptake of maize crop. African Journal of Agricultural Research 11(8): 661-673.

2. Aliasgharzad, N., E. Shirmohamadi and S. Oustan. 2009. Siderophore production by mycorrhizal sorghum roots under micronutrient deficient condition. Soil and Environment 28: 119-123.

3. Atkinson, C. J., J. D. Fitzgerald and N. A. Hipps. 2010. Potential mechanisms for achieving agricultural benefits from biochar application to temperate soils: A review. Plant and Soil 337: 1-18.

4. Barea, J. M., R. Azcon and C. Azcon-Aguilar. 2002. Mycorhizosphere interactions to improve plant fitness and soil quality. Antonie van Leeuwenhoek 81: 343-351.

5. Becker, M. and F. Asch. 2005. Iron toxicity in rice - conditions and management concepts. Soil Science and Plant Nutrition 168: 558-573.

6. Beesley, L. and M. Marmiroli. 2011. The immobilisation and retention of soluble arsenic, cadmium and zinc by biochar. Environmental Pollution 159: 474-480.

7. Bernal, M. P. and S. P. McGrath. 1994. Effects of $\mathrm{pH}$ and heavy metal concentrations in solution culture on the proton release, growth and elemental composition of Alyssum murale and Raphanus sativus L. Plant and Soil 166: 83-92.

8. Bramryd, T. 2001. Effect of liquid and dewatered sewage sludge applied to a Scot pine stand (Pinus sylvestris L.) in central Sweden. Forest Ecology and Managemen 147: 197-216.

9. Castro, E., P. Manas and J. De Las Heras. 2009. A comparison of the application of different waste products to a lettuce crop: Effects on plant and soil properties. Scientia Horticulturae 123: 148-155. 
10. Domene, X., S. Mattana, K. Hanley, A. Enders and J. Lehmann. 2014. Medium-term effects of corn biochar addition on soil biota activities and functions in a temperate soil cropped to corn. Soil Biology and Biochemistry 72: 152-162.

11. Enders, A., K. Hanley, T. Whitman, S. Joseph, J. Lehmann. 2012. Characterization of biochars to evaluate recalcitrance and agronomic performance. Bioresource Technology 114: 644-653.

12. Gartler, J., B. Robinson, K. Burton and L. Clucas. 2013. Carbonaceous soil amendments to biofortify crop plants with zinc. Science of the Total Environment 465: 308-313.

13. Havlin, J. L., J. D. Beaton, S. L. Tisadale and W. L. Nelson. 2005. Soil Fertility and Fertilizers: an Introduction to Nutrient Management. $7^{\text {th }}$ Edition. Pearson Education Inc., Upper Saddle River. New Jersey, USA.

14. Inal, A., A. Gunes, O. Sahin, M. B. Taskin and E. C. Kaya. 2015. Impacts of biochar and processed poultry manure, applied to a calcareous soil, on the growth of bean and maize. Soil Use and Management 31: 106-113.

15. Ippolito, J. A., J. M. Novak, W. J. Busscher, M. Ahmedna, D. Rehrah and D. W. Watts. 2012. Switchgrass biochar affects two Aridisols. Environmental Quality 41: 1123-1130.

16. Ippolito, J. A., K. A. Spokas, J. M. Novak, R. D. Lentz and K. B. Cantrell. 2015. Biochar elemental composition and factors influencing nutrient retention. pp. 138-164. In: Lehmann, J. and S. Joseph (Eds.), Biochar for Environmental Management, 2 Ed. Routledge, Earthscan.

17. Jeffries, P. 2001. Achievements in the Past and Autlook for the Future of AMF. Research School of Biosciences, University of Kent. Canterbury. Kent.

18. Jifon, J. L., J. H. Graham, D. L. Drouillard and J. P. Syvertsen, 2002. Growth depression of mycorrhizal Citrus seedlings grown at high phosphorus supply is mitigated by elevated CO. New Phytology 153: 133-142.

19. Jin, H. Y. 2010. Characterization of microbial life colonizing biochar and biochar-amended soils. PhD. Thesis, Cornell University.

20. Lehmann, J., M. C. Rillig, J. Thies, C. A. Masiello, W. C. Hockaday and D. Crowley. 2011. Biochar effects on soil biota e a review. Soil Biology and Biochemistry 43: 1812-1836.

21. Leoni, L., C. Amborsi, A. Petrucca, and P. Visca. 2002. Transcriptional regulation of pseudobactin synthesis in the plant growth promoting pseudomonas B10. FEMS Microbiology Letter 208: 219-225.

22. Lindsay, W. L. and W. A. Norvell. 1978. Development of a DTPA soil test for zinc, iron, manganese, and copper. Soil Science Society of America Journal 42: 421-428.

23. Méndez, A., A. Gómez, J. Paz-Ferreiro and G. Gascó. 2012. Effects of sewage sludge biochar on plant metal availability after application to a Mediterranean soil. Chemosphere 89(11): 1354-1359.

24. Mengel, K. and E. Kirkby. 2001. Principles of Plant Nutrition. $5^{\text {th }}$ Ed., International Potash Institute, Bern, Switzerland.

25. Namgay, T. and B. Singh. 2010. Influence of biochar application to soil on the availability of $\mathrm{As}, \mathrm{Cd}, \mathrm{Cu}, \mathrm{Pb}$ and $\mathrm{Zn}$ to maize (Zea mays L.). Australian Journal of Soil Research 48: 638-647.

26. Nigussie, A., E. Kissi, M. Misganaw and G. Ambaw. 2012. Effect of biochar applica-tion on soil Properties and nutrient uptake of Lettuces (Lactuca sativa) grown inchromium polluted soils. Am-Euras, American-Eurasian Journal of Agricultural \& Environmental 12 (3): 369-376.

27. Novak, J. M., I. M. Lima, B. Xing, J. W. Gaskin, C. Steiner, K. C. Das, M. Ahmedna, D. Rehrah, D. W. Watts, W. J. Busscher and H. Schomberg. 2009. Charcaterization of designer biochar produced at different temperatures and their effects on a loamy sand. Annals of Environmental Science 3: 195-206.

28. Rajkovich, S., A. Enders, K. Hanley, C. Hyland, A. R. Zimmerman and J. Lehmann. 2011. Corn growth and nitrogen nutrition after additions of biochars with varying properties to a temperate soil. Biology and Fertility of Soils 48(3): 271-284.

29. Rengel, Z. and V. Romheld. 2000. Root exudation and Fe uptake and transport in wheat genotypes differing in tolerance to Zn deficiency. Plant and Soil 222: 25-34.

30. Salim, B. B. M. 2016. Influence of biochar and seaweed extract applications on growth, yield and mineral composition of wheat (Triticum aestivum L.) under sandy soil conditions. Annals of Agricultural Science 61: 257-265.

31. Schusler, A. 2001. A new fungal phylum, the Glomeromycota: Phylogeny and evolution. Mycological Research 105: 1413-1421.

32. Sohi, S. P., E. Krull, E. Lopez-Capel and R. Bol. 2010. A review of biochar and its use and function in soil. Advances in Agronomy 105: 47-82.

33. Sparks, D. L., A. L. Page, P. A. Helmke, R. H.Loeppert, P. N. Soltanpour, M. A. Tabatabai, C. T. Johnston and M. E. Sumner. 1996. Methods of soil analysis Part 3- Chemical methods. Soil Science Society of America Book Ser. 5, Madison, Wiscons in, USA.

34. Tao, S., W. X. Liu, Y. J. Chen, F. L. Xu, R. W. Dawson, B. G. Li, J. Cao, X. J. Wang, J .Y. Hu and X. Fong. 2004. Evaluation of factors influencing root-induced changes of copper fractionation in rhizosphere of a calcareous soil. Environmental Pollution 129: 5-12.

35. Toal, M. E., C. Yeomans, K. Killham and A. A. Meharg. 2000. A review of rhizosphere carbon flow modelling. 
Plant and Soil 222:263-281.

36. Uchimiya, M., K. T. Klasson, L. H. Wartelle and I. M. Lima. 2011. Influence of soil properties on heavy metal sequestration by biochar amendment: 1.Copper sorption isotherms and the release of cations. Chemosphere 82: 1431-1437.

37. Vahedi, R., M. H. Rasouli-Sadaghiani and M. Barin. 2018. The effect of rhizosphere on availability of soil elements in the presence of biochar and compost pruning waste and mycorrhizal. Journal of Soil Management and Sustainable Production 8(1): 107-124. 


\title{
Bioavailability of Selected Micronutrients as Affected by Biochar and Compost of Trees Pruning in the Presence of Mycorrhiza at Wheat Rhizosphere
}

\author{
R. Vahedi and M. H. Rasouli-Sadaghiani ${ }^{1^{\star}}$
}

(Received: December 5-2018; Accepted: April 9-2019)

\begin{abstract}
Synergistic relationships between mycorrhizal fungi (AMF) and organic compounds affect the mobility of the micronutrient elements in the rhizosphere and improve their bioavailability. In order to evaluate the effect of biochar and pruning waste compost of apple and grape trees, as well as AMF, on micronutrient bioavailability in calcareous soil at the wheat rhizosphere, an experiment was carried out in a completely randomized design under greenhouse conditions in a rhizobox study. Some factors including the organic sourses (pruning waste biochar, pruning waste compost and control), microbial inoculation (AMF and no inoculation) were considered. At the end of the growth period, Organic matter (OM) content and bioavailability of micronutrients including iron (Fe), Zinc (Zn), Copper (Cu) and Manganese $(\mathrm{Mn})$ in the rhizosphere and their uptake by wheat plant were determined. The results indicated that $\mathrm{OM}, \mathrm{Fe}, \mathrm{Zn}, \mathrm{Mn}$ and $\mathrm{Cu}$ were significantly increased in the rhizosphere soil under the influence of organic sources and mycorrhizal inoculation. Furthermore, biochar application in the mycorrhizal tratment resulted in $74.73 \%$ and $19.28 \%$ increase in Fe and Mn, as compared to non-inoculated conditions, in rhizosphere. The presence of mycorrhizal fungi increased the bioavailability of $94.66 \%$ and $29.54 \% \mathrm{Zn}$ and $\mathrm{Cu}$ in the compost treatment, as compared to non-inoculated ones. Application of organic sources and mycorrhizal inoculation increased the micronutrient uptake and plant dry weight.
\end{abstract}

Keywords: Organic matter, Micronutrient elements, Rhizosphere, Wheat

1. Department of Soil Science, Faculty of Agriculture, Urmia University, Urmia, Iran.

*: Corresponding Author, Email: m.rsadaghiani@urmia.ac.ir 